Portland State University

PDXScholar

1984

\title{
Strong-minded woman figures in a time of crisis : Maria Stuart, Penthesilea, Sappho
}

Inger M. Olsen

Portland State University

Follow this and additional works at: https://pdxscholar.library.pdx.edu/open_access_etds

Part of the German Literature Commons

Let us know how access to this document benefits you.

\section{Recommended Citation}

Olsen, Inger M., "Strong-minded woman figures in a time of crisis : Maria Stuart, Penthesilea, Sappho" (1984). Dissertations and Theses. Paper 3521.

https://doi.org/10.15760/etd.5405

This Thesis is brought to you for free and open access. It has been accepted for inclusion in Dissertations and Theses by an authorized administrator of PDXScholar. Please contact us if we can make this document more accessible: pdxscholar@pdx.edu. 
AN ABSTRACT OF THE THESIS OF Inger $M$. Olsen for the Master of Arts in German November 16, 1984.

Title: Strong-minded Woman Figures in a Time of Crisis: Maria Stuart, Penthesilea, Sappho.

APPROVED BY MEMBERS OF THE THESIS COMMITTEE:
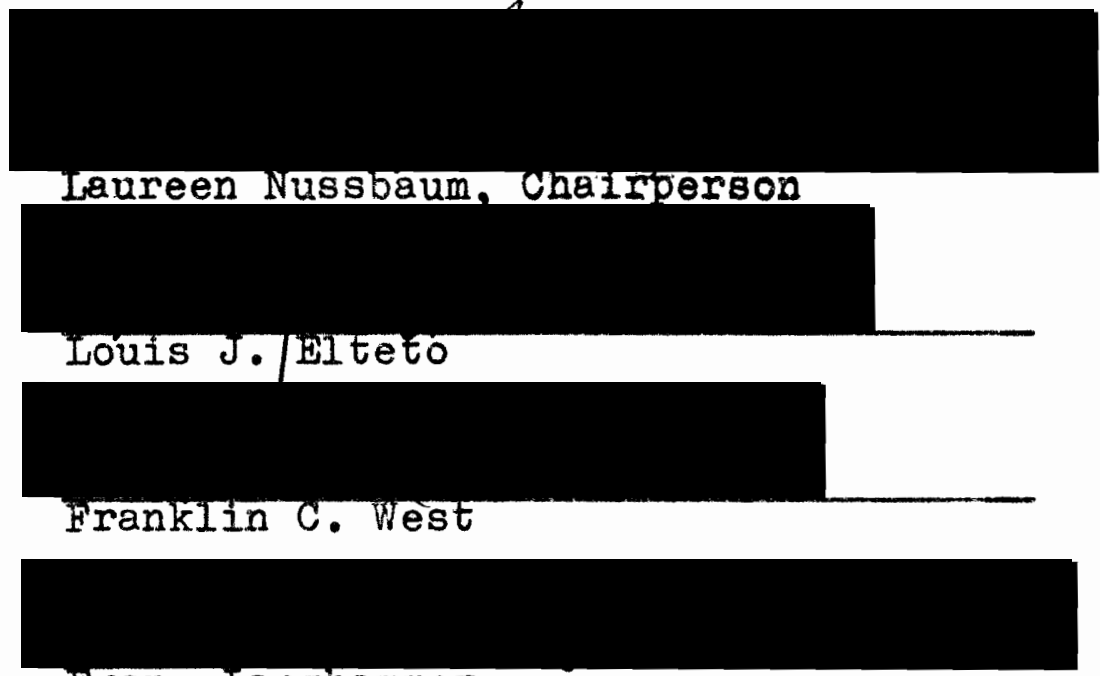

Franz Langhammer

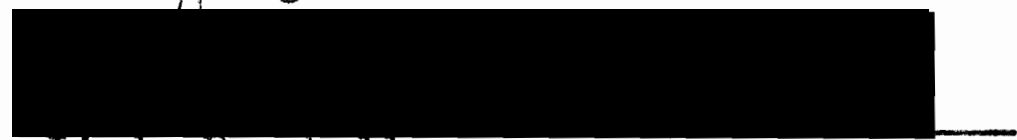

uinda parsha11

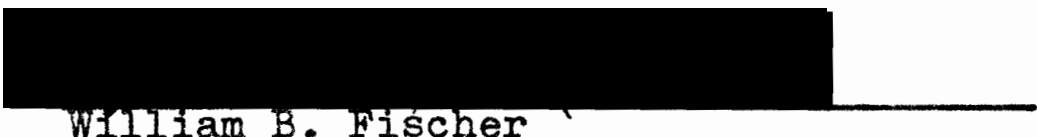

The strong-minded woman as a character capable of genuine self-determination has not received nearly as much literary attention and study as the less psychologically and socially aware sublime woman, the innocent woman, and the femme fatale. Consequently, the strong-minded woman is only an occasional literary 
phenomenon and is absent entirely during some literary periods.

There are a number of exceptions to whom I want to draw attention. In Schiller's Maria Stuart, Heinrich von Kleist's Penthesilea, and Grillparzer's Sappho the female protagonists are all treated as individuals in their own right who act on choices according to their values. They are strong-minded in the sense they are aware their choices may be lifethreatening if not fatal; but to do otherwise is unthinkable. These are figures not pressed by the writers to make flawed character shifts to escape their dilemmas. They function in universes that allow them to make what they consider the best if not the most pleasant choices for themselves in complex ethical circumstances.

These works were all written in the stressed society created by the tension of the Napoleonic era when social changes were taking place. Feudalism was ended, the guild structure was weakened, the Jews were emancipated, broader education for children became the rule as did the greater opportunities for self-expression by women.

That the writers chose to select women during this pexiod is not at variance with the prevailing social norms. Androgeny was in vogue and they were familiar with it. The strong-minded woman appears to me to be 
a Iiterary archetype. The writers have at least implied the need for strong women and through that created what C.G. Jung called "a true work of art" "the significance of which resides in the fact that it has escaped from the limitations of the personal and has soared beyond the persoral concerns of its creator." Northrop Frye underscores the legitimacy of archetypal criticism by stressing that it is "primarily concerned with literature as a social fact as a mode of communication." What Jung says is central to my thesis, because I have found no direct statement or discussion of the strong-minded woman in the writings of the three poets under discussion. In fact, Kleist and Schiller even made very traditional remarks about the role their own women should play. But it is not my purpose to discuss their motivations for their work. If they professed to have conventional thoughts about women's social roles, they did not let these feelings influence their art.

In the recent work by Lee R. Edwards called Psyche as Hero I have found a serious attempt to study those woman figures in literature who have been treated as strong-minded persons, every bit as heroic as their better known male counterparts.

Thus the purpose of tinis thesis is to establish that the strong-minded woman exists as a literary figure, that she is a fully developed character 
capable of forming meaningful and even traditional relationships when allowed by circumstances. She is capable of relying on her own abilities and is willing to take the consequences stemming from her actions. 
STRONG-MINDED WOMAN FIGURES IN A TIME OF CRISIS: MARIA STUART, PENTHESILEA, SAPPHO

by

INGER M. OLSEN

A thesis submitted in partial fulfillment of the requirements for the degree of

MASTER OF ART'S

in

GERMAN

Portland State University

1985 
TO THE OFFICE OF GRADUATE STUDIES AND RESEARCH:

The members of the Committee approve the thesis of Inger M. Olsen presented November 16, 1984.

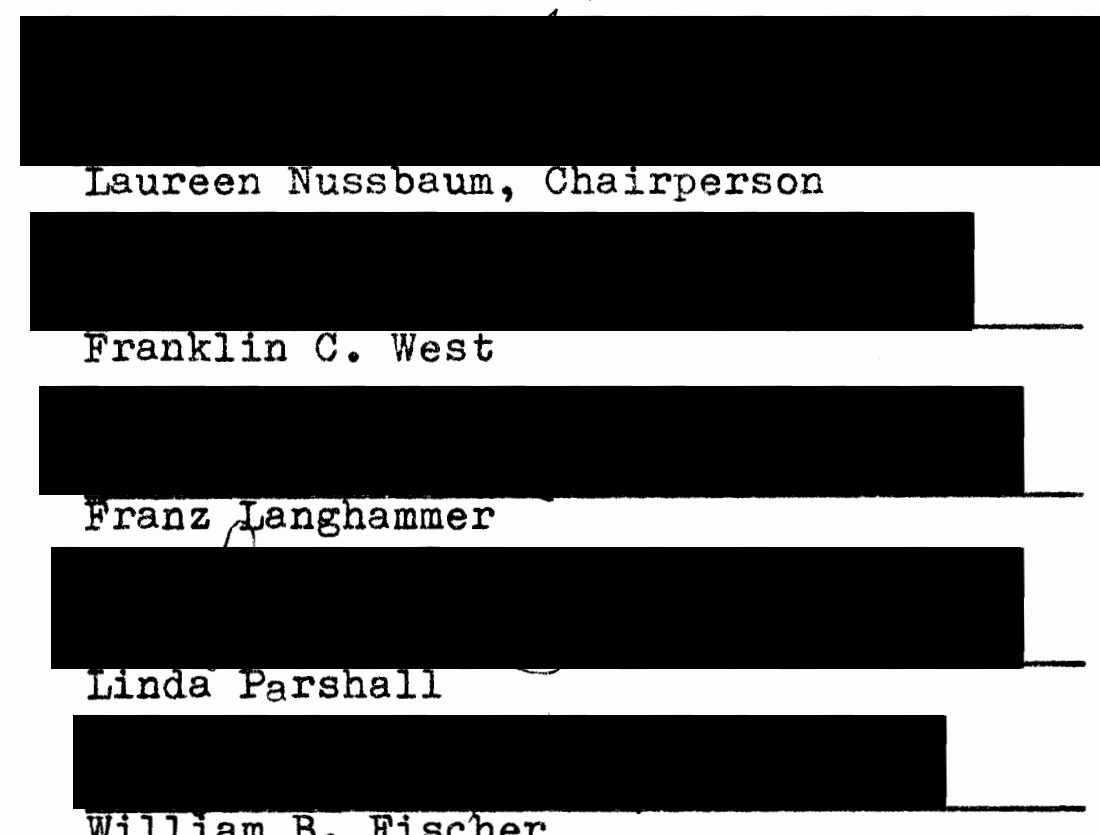

APPROVED:

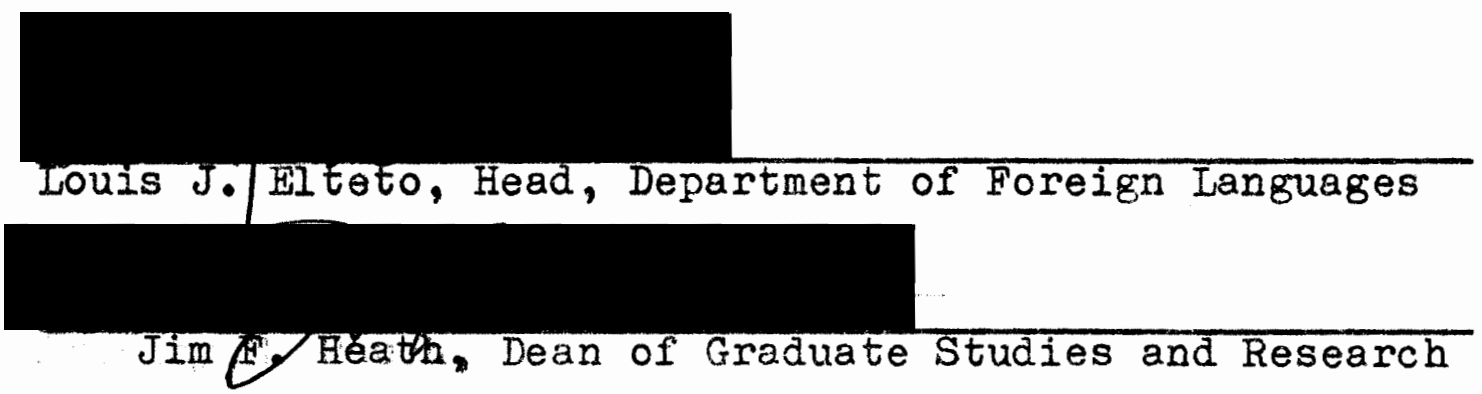


Thanks to my mother in memoriam, to my father, and to Norm and Jarl.

Special thanks to Professor Laureen Nussbaum for years of unlimited advice and support.

Thank you goes to the German section as a whole for giving me the opportunity to learn, teach, and hopefully grow. 
TABLE OF CONTENTS

PAGE

ACKNOWLEDGMENTS . . . . . . . . . . . . . . iii CHAPTER

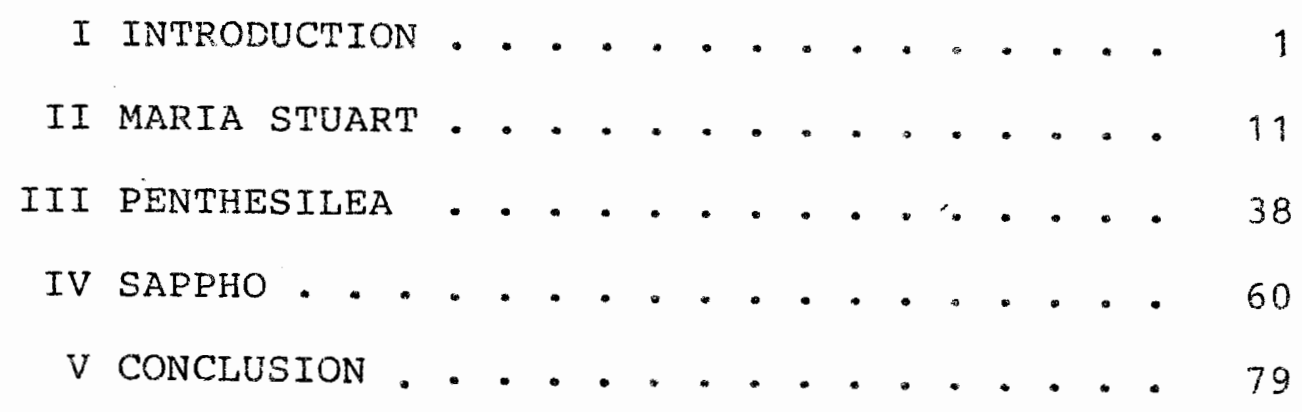

BIBLIOGRAPHY . . . . . . . . . . . 88 


\section{CHAPTER I}

\section{INIRODUCTION}

Women in German literature are often treated as representations of types rather than described as individuals. Some examples are the title figure of Goethe's Iphigenie, the epitome of virtue; prostitutes like Jenny in Bertolt Brecht's Dreigroschenoper;

suffering wives and daughters such as Effi in Theodor Fontane's Effi Briest; females who let themselves be used by men and by circuinstances, the most famous example of which is Gretchen in Goethe's Faust; ideal housewives Iike the wife in Hans Fallada's Kleiner Mann, was nun?; manipulating women such as the old lady in Durrenmatt's Besuch der alten Dame. They are cast as types: Virtue personified, adulteresses, witches, and bitches--but rarely as persons capable of or fit for true human action good or evil. Obviously the above is exaggerated but it seems to me that such a character exists and she can be defined as follows: She is independent, her character has flaws and strengths, e.8. she will, when pushed to extremes lose her temper even though this may be used against her, and her strength is her ability to 
meet adversity without breaking down. She initiates actions which determine the course of her life. She forms close companionships--a situation in which one usually finds male heroes. She commits heroic acts, experiences catharsis, and as often as not she is killed in the process. I shall try to find reasons why this figure has been employed infrequently and why the works in which they appear seem to have been so few. I should like to discover why the works which focus on these complex and strong-minded women seem to have come forth during times of great social and political upheavals such as the Migrations, the Thirty Years' War, World War I, and perhaps World War II.

In order to narrow the scope of the study I am limiting the number of works to three and I shall confine the scope to one period in history. The works are Maria Stuart by Friedrich Schiller, Fenthesilea by Heinrich von Kleist, and Sappho by Franz Grillparzer. The plays were all tragedies, and they were written duxing or shortly after the Napoleonic era.

In keeping with the Aristotelian notion that great tragedies must be concerned with the gods or the great figures of this earth each play has as its main character a queen who dies because of a flaw in her character. IThe poets had but few great women to choose from when they decided to write aramas with female 
protagonists since there had only been a few female rulers in history. But in the second half of the $18 \mathrm{th}$ century there had been Catherine the Great of Russia and Maria Theresia of Austria-Hungary, hence due to the social changes of the previous era it had become reasonable and acceptable to write plays with women in the leading roles.

The plays of my thesis are all dramas written in the iambic meter. They were constructed according to the classic pattern even though Penthesilea does not have five acts. Two, Penthesilea and Sappho, were placed in the time of the Greeks, Maria Stuart was placed in a time closer to the writer's own period.

Schiller (1759-1805), a poet and professor of history, had written some scholarly work about the Elizabethan era. In a letter to Goethe, Schiller announced that he had read a reference to Maria Stuart while be was studying the Elizabethan government. 2 Heinrich von Kleist (1777-1811), a poet and a civil servant, had come to loathe Napoleon and the destruction his regime had wrought. 3 Kleist mixed his own problems into his work when writing the play Penthesilea. Penthesilea's conflict concerning her duties as the queen of the Amazons and her own feelings as an individual mirrors Kleist's own predicament. Franz Grillparzer (1791-1872) worked as a civil servant while writing for the stage. The Napoleonic Wars seem to have made less of 
an impression on him than on Schiller and Kleist, possibly due to geographical distance. When he chose Sappho he stated he wanted material which he had to fight to grasp as a challenge for his own pleasure and enrichment. 4

The titles of the plays are also the names of the main characters. All are women who have fenale counterparts, companions, or rivals. Each experiences unrequited love and each experiences catharsis. They are all ruling queens: Maria Stuart was queen of the Scots, Penthesilea was queen of the Amazons, and Sappho was queen of the poets. They take a heroic stand and become entangled in dilemmas they can not resolve. Because of their inflexible modes of thinking they pursue their goals even if they must die in the process. Fate takes precedence over free will. As a consequence they all die violent deaths as the classical drama required. 5 Two of them, Penthesilea and Sappho, commit suicide; one, Maria stuart, is executed.

There are parallels that may not be relevant but are all the same interesting. ${ }^{6}$ Each of the writers had different levels of success which seems to be linked to Goethe with whom they all sought contact. Indeed, Schiller became Goethe's friend. Grillparzer was well received by Goethe but could not bow to the notion that German literature was greater than Austrian literature. Grillparzer was part of the Austrian tradition though 
his play Sappho was written with Goethe as his standard and model. ${ }^{7}$ Heinrich von Kleist tried in vain to persuade Goethe to stage his play Penthesilea at the theater in Weimar; but Goethe refused as the drama did not have the traditional five acts and therefore appeared rambling. 8 Maria Stuart, Penthesilea, and Sappho were written in 1800,1808 , and 1817 respectively. Interestingly enough, all three authors created other female main characters within the same period, such as Johanna in Die Jungfrau von Orleans by Schiller; the title figure of Katchen von Heilbronn by Heinrich von Kleist, and Medea in the third part of the trilogy Das goldene Vliess by Franz Grillparzer. But while haria Stuart, Penthesilea, and Sappho are supported by their surroundings, Johanna, Katchen, and Medea are women who take steps into men's society without solid backing by men or women, and this appears to me as a problem. The latter three are not understood by their families and friends and are therefore rejected or scolded. Maria Stuart, Sappho, and Penthesilea are not understood either; but it is seen as inevitable by their companions that they must follow their destined paths. No condernnation follows them. Their right to be different is not questioned, nor are they ridiculed, scolded, or rejected. They are pitied and mourned because of their fates. Johanna, the title figure of Die Jungfrau von Orleans by Schiller has some of the characteristics 
of the strong-minded woman; but she does not initiate any of the actions which determine the course of her life. In fact, she is not even allowed to fall in love. Instead, she is chosen by fate to be the medium though which France is saved and in the course of the play she loses the acceptance and the companionship among the nobles whom she aides. In the end she dies as she lived, an outsider, because she is more a medium than a person. kytchen von Heilbronn by Heinrich von Kleist is a play in five acts which has a happy ending. Katchen is chosen by fate to follow her man. In the end he acknowledges that she is his rightful birde. She steps outside the confines of her family and social group in order to fulfill the prophecy of her dream. During this period she is followed by her father and his concern for her welfare. She is helped by other people as well to achieve her goal. Kutchen is protected by them when she becomes unwilling to do so herself. She is loved and cared for but treated like a child, not a woman when she goes her own ways. Katchen is destined for a life with her intended husband. She just follows the call to find him and to stay near him till he sees the error of his ways. He changes and grows and she does not. Katchen falls outside this study because she does not experience catharsis.

Medea, the third part of Franz Grillparzer's trilogy, Das goldene Vliess, does not fit into this 
examination of works, either. In the first two parts one sees Medea as a child and young woman. At the point where we now meet her she has lost all innocence. Her overriding wish is to avenge the deaths of her father and brother and the wrong done to her, even though this entails destruction of those who are close to her, both the one who loves her, Gora, and those who fear her, her children. Medea has been hurt and wants to make sure the world knows her pain. The killing of her rival, Kreusa, ensures her that not only Jason; but also Kreusa's father are hurt. She kills her children because they chose Kreusa and not her as their mother. Gora faces death because she brought the box of flames to Kreusa on Medea's command. Medea ends as a lonely person. One could claim she was a victim of discrimination caused by xenophobia. Although catharsis ensures her the approval of the gods in her destructive venture, Medea is so stunted, she grows evil and is no more a full person. She only walks away seemingly unscathed. In this respect Medea is close to Kriemhilde of the Nibelungenlied and the title figure of Brecht's Mutter Courage neither of whom learn from experience either. Other contemporaries of our three poets, such as Goethe, wrote plays with female title roles. The aforementioned Iphigenie auf Taurus is one. It falls outside this study for several reasons. First, it was written in its first version in 1779 and the fourth and final 
version came three Jears before the French Revolution in 1786. Second, though Iphigenie is the title figure of the play she does not follow her own mind to pursue her own goals. She uses her strength and ability to reconcile her brother Orest and Thoas, king of Paurus, and thereby she saves her brother from himself while she saves his life as well as her own. Iphigenie does not at any time rebel against her fate; she remains sublime. 9

On balance one must say the plays'with female protagonists written in the early $1800 \mathrm{\prime} \mathrm{s}$ were numerous; but the strong and independent yet fully human woman character is illustrated and exemplified in Maria Stuart, Penthesilea, and Sappho. They are the subjects of my thesis. 
NOTES

1 Aristotle's Poetics, trans. S. H. Butcher, introd. Francis Ferguson (New York: Hill and Wang, 1961), p. 77 .

2 Friedrich Schiller, Maria Stuart (Stuttgart: Reclam, 1978), p. 140 .

3 Bruno Boesch et a11., Deutsche Literaturgeschichte in Grundzugen (Bern: A. Francke AG Verlag, 1961), p. 325 .

4 Franz Grillparzer, Sappho, ed. Keith Spalding (New York: St. Martin's Press, 1965), p. 117. 5 Aristotle's Poetics p. 74.

6 The authors' liveswere of varying lengths; but all their works were written before they turned fifty. Kleist took his own life. Schiller died overworked and ill. Grillparzer died old but stopped publishing after his play Weh dem, der lugt was rejected at its first performance in Vienna in 1840.

7 W. Grabert and A. Mulot, Geschichte der deutschen Literatur (Munchen: Bayerischer Schulbuch-Verlag, 1965), p. 287.

8 Heinrlch von Kleist, Sumtliche Werke und Briefe, ed. Helmut Sembdner (Munchen: Carl Hanser Verlag, 1982), IV, p. 806 . 
9 In a letter to Schiller dated, Jena, 19. Januar 1802, Goethe wrote the following about his drama Iphigenie: " . . es ist ganz verteufelt human. . ." 
CHAPTER II

MARIA STUART

After a visit to weimar in 1799 Schiller could not find peace. He wrote to Goethe that in order to settle down he had started the study of history and especially the history of Maria stuart. Later in the year he wrote to Goethe again on the subject of history and the creative use of historical figures:

Uberhaupt glaube ich, dass man wohl tun wllrde, immer nur die allgemeine Situation, die Zeit und die Personen aus der Geschichte zu nehmen und alles Ubrige poetisch frei zu erfinden wodurch eine mittlere Gattung von Stoff entstunde, welche die Vorteile des historischen Dramas mit dem Erdichteten vereinigt. 1

What Schiller wanted, according to this, was to create a figure who was rooted in history, but whose character was the poet's own creation. Thus the hero or heroine would become reflections of the writer's own time.

In the same year Schiller wrote to Goethe about his portrayal of Maria Stuart:

Meine Maria wird keine weiche stimmung erregen, es ist meine Absicht nicht, ich will, sie immer als ein physisches Wesen halten, . . Sie empfindet und erregt keine zalrtlichkeit, ihr Schicksal ist nur heftige Passionen zu erfahren und zu entzunden. Bloss die Amme flhlt zdrtlichkeit fllr sie. ${ }^{2}$

Schiller was concerned about the political situation of his day and especially the question of freedom was on his 
mind. This can be seen in the following quotation from Burschell's Schiller study:

Unter der Idee der Selbstbestimmung aber verstand Schiller zugleich die der Freiheit, das zentrale Problem sowohl seines Lebens wie seines Schaffens.

Burschell also quotes Goethe, who said towards the end of his life when Schiller was long since dead:

Durch alle Werke Schillers geht die Idee von Freineit und diese Idee nahm eine andere Gestalt an sowie Schiller in seiner Kultur weiterging und selbst ein anderer wurde. In seiner Jugend war es die physische Freiheit, die ihm zu schaffen machte und die in seine Dichtung Uberging; in seinem sputeren Leben die Ideelle.4

Summing up the esthetic concerns of the mature Schiller, Burschell adds:

Was er unter Usthetischen Erziehung des Menschen verstand war nichts anderes als die Erziehung zu einer hoheren Freiheit, 5 aus der dann erst der Vernunftstaat entstehen konne. 5

In June Schiller wrote the outline for a play the heroine of which was to be Maria stuart. She fulfilled his desire to write about a historical person. In writing the play he could also make a statement about a person's growth in mental stature, and he could make a statement about physical and mental freedom. In his play Schiller used the fact that Elizabeth and Mary were rivals for the English throne, the circumstance that they were related, and the historical facts pertaining to French interest in British affairs. With regard to Elizabeth's feelings toward her rival it is a historical fact that the English monarch 
was very insecure because her looks were not as striking as Mary's, and that furthermore she was 9 years older than the Scottish queen. The English queen was a vacillating person. She kept Mary imprisoned for 19 years (1568-1587) before the execution took place. 6 Elizabeth avoided as much as possible taking anybody's side. This was perhaps caused by her upbringing. She was the daughter of Henry VIII and the ill-fated Ann Boleyn and had never had the comforts of a loving home. At any rate Mary, Queen of Scots, did suffer under Elizabeth's indecisiveness. Furthermore Robert Dudley, Count of Leicester, was indeed Elizabeth's favourite; but he had not courted the Scottish queen, as Schiller portrays him doing.

The climax of the play is the meeting between the two queens. This encounter is not an historical event. All through her imprisonment Mary pleaded for a meeting but only in this drama does it take place. ${ }^{7}$ The poet portrays Mary as a warm and caring person, who could at all times count on her underlings' loyalty; that is an historical fact as is her growth from a vivacious to a reflective person. 8

In the play Schiller takes care to illuminate Maria Stuart's personality in her relationship to other people. It is not revealed in soliloquies, but rather in interactions, because of the literary convention of Schiller's time. She portrayed as considerate of her servants, and the consideration is reciprocated. Hanna Kennedy, her nurse, is as devoted to her as a mother. She is also the one person 
Maria wants to have close when the end is at hand. Margareta Kurl, a lady's maid, goes so far as to curse her husband, who had testified against Maria $(M . V, 2) .{ }^{9}$ He, for his part, goes mad when he hears that Maria has been sentenced to death because of his and the other secretary's revelations. The scribes had been made to confess. Under threat of torture they had stated that Maria had dictated letters to them in which she asked for help in conducting an uprising against Elisabeth. It had not been considered prudent to bring Kurl and the other scribe in front of Maria to get her to confirm the story. Her servants' devotion to her was too well known!

In act I, scene 2 Maria asks very concernedly about the fate of her servants in general. She is reassured by Paulet, her jailor, that they are not suffering (M.I,7). The queen defends Kurl and his confessions as well as those of his fellow secretary Nau. She understands what the threat of torture does to people. She insists on seeing them. She has been told by paulet that there is a law in England which demands that those who speak for the plaintiff be confronted with the defendant; but she does not fall under it, because of her alleged linkage with the conspirators Babbington and Mendoza, the Spanish ambassador (M.I,7). Paulet believes that Babbington and Tichburn could, with advantage, have confronted her; but the treasurer, Wilhelm Cecil, Count of Burleigh, is emphatically against it (M.I, 8).

Queen Mary had a reputation of fascinating men and of 
being liberal with her favors towards them. Schiller used these propensities to heighten the tension of his drama. Not only dia he enlarge upon the historical role of count Leicester, as mentioned above, he also introduced a nonhistorical figure, a passionate young man by name of Mortimer. Schiller's Mortimer is the nephew of Maria's warden, the honorable old Paulet. Mortimer plots to liberate Maria and he expects her favors in return for effecting her escape. The Scottish queen is, however, not what she once was. When the passionate young man tells her he wants to murder his uncle, the warden, whom he calls his "second father," claiming Maria as his reward, the Scottish queen declines the offer because she sees too much blood around her. Mortimer's advances are met with a horrified refusal. The would-be conqueror then states, "Die Krone ist von deinem Haupt gefallen, . ." (M.III,6). As he presses her, Maria's feeling of helplessness comes to the surface when she turns to Hanna for protection. There were no guards she could summon to rid herself of the unwelcome advances. Rather than feeling flattered and happy because she is still attractive Maria seeks comfort from Hanna her surrogate mother. She needs solace not flattery.

This had been different in the past. Both as a woman and a queen she had dared live in a fashion only acceptable for men. One of the problems she had had with her husband, Darnley, was, according to Hanna, that he had wanted to be 
king and he had neither respected her as a woman nor as a queen $(M . I, 4)$. When Kennedy defends Maria's submission to Bothwell's advances the queen makes it clear that she knew to what she was agreeing. She says, "Seine klinste waren keine andre [sic!] als seine Mannerkraft und meine schwachheit" $(M . I, 4)$. But now she, not Mortimer, is the one to set the rules.

While the queen of scotland has nothing but good wishes for her servants once she knows for certain she must die, not all of them are equally forgiving. That holds particularly for Margareta Kurl, the wife of the disloyal secretary. When she arrives in the end to fetch Hanna she sees Melvil, Maria's former steward. He reminds Margareta of her husband's testimony. Upon Melvil's confirmation that Kurl has testified against her queen she promises to make his life miserable once he is set free, which will be right after the queen's death. When Maria enters dressed in white she gives them encouragement and tells them not to cry. She is going to be free. The queen is very pleased that Melvil has come. He will make sure that she will be vindicated posthumously. Maria asks further questions about former members of her staff. She divides her possessions among her present servants. Hanna is asked to perform one last service. She is to tie the scarf over Maria's eyes before the execution takes place $(M, V, 6)$.

No matter what happened to Maria she always had time 
for her servants. She did not let them suffer for any of the pain and frustration she must have felt. Maria realized very clearly that they were small people who had no power as their adversaries were the mightiest of the land. She tried to make sure that if they desired they would be allowed to leave freely for Scotland or France once she was dead $(M . V, 6)$.

The servants all leave her and she is alone with Melvil. It turns out that he has become a priest who can lead her in the last confession and the Lord's Supper. Maria reveais that all her hatred is gone and she is ready to die. The murder of Darnely is the only thing still bothering her conscience although she had confessed it many years ago. Under no circumstance will she accept any responsibility for any attack on Elizabeth's life. Melvil then grants her absolution without penance. She is ready and serene. Maria dies eine schbne seele because she has fulfilled schiller's prerequisite for becoming a sublime soul. She has indeed internalized her ethical feeelings to a point where she can trust the leadership of her will.10

According to Schiller's intentions the captive Maria had the warmest relationship with Hanna Kennedy her nurse. It is the nurse who comforts the scottish queen when she agonizes over the murder of Darnley. Kennedy looks after the queen as a mother, and over the years the distance of rank between them has been obliterated. The nurse, for example, admonishes the queen in the garden scene that the prison 
has only grown a little larger and that her death sentence has been pronounced $(M . I I I, 1)$. Kennedy also becomes very concerned after Maria has belittled Elisabeth, who is after a11, the queen both in name and reality (M.III,5). The fiasco of the meeting between the two queens--upon which I will dwell later--has made the death of Maria stuart unavoidable. Shortly before her death, Schiller emphasizes once more his heroine's concern for her underlings and her closeness to Hanna Kennedy.

The climax of the play is the meeting between the two queens in the third act. Everything before that pivotal scene III, 4 leads up to it, and the denouement thereafter more or less derives from it. The Scottish and the English queens had long been rivals both as monarchs and as women. Maria is younger than Elisabeth. She has grown up at the French court seemingly pampered, whereas Elisabeth grew up in a very hostile climate without the protection of affectionate relatjves. Schiller adds to the historical rivalry by having Robert Dudley, Count of Leicester, cast an eye on the recently widowed Maria when she returned from France to Scotland. However, he had abandoned her for Elisabeth when the latter seemed the bigger prize. Once she became queen of England, Elisabeth had not shown any signs of desiring to marry, and Dudley's frustration was immense. Elisabeth does confide in him about Maria's shortcomings as a person. The English queen is especially upset because Maria has an easy- 
going attitude towards life. Leicester himself explains why he has come between the two queens:

Mein Ehrgeiz war es, der mich gegen Jugend Und Schonheit fühllos machte. Damals hielt ich Mariens Hand fur mich zu klein, ich hoffte Auf den Besitz der KBnigin von England.

(M.II, 8)

Neither Elisabeth nor Maria is unaware of this and it aggravates Elisabeth.

Historically Dudley did not actually show any interest in Mary, Queen of Scots. He was the favourite of Elizabeth and it was long thought they would somehow be able to marry. When Dudley's wife died under very strange circumstances there was, however, no way they could think of a union unless they were ready to face the same opposition Mary and Bothwell. met after the murder of Darnley. Elizabeth was the one who suggested Leicester could be a candidate for husband for Mary. 11 Maitland, a Scottish nobleman, tactfully but firmly refused the great sacrifice on behalf of the Scottish nation. Mary herself was only agreeable to such a match if Dudley could guarantee that her claim to the British crown would be recognized. This is in contrast to the deep feelings schiller attaches to the relationship between Maria and Dudley. In his play the poet uses those feelings to deepen the utter loneliness Elisabeth is left with when in the end she is told: "Der Lord lasst sich/ Entschuldigen er ist zu Schiff nach Frankreich." (M.V,15). Elisabeth had won the undisputed right to her throne by killing Maria but lost everything as 
a person. To summarize, Schiller did nothing to change the basic character of Mary and Elizabeth. He made two significant changes in two of the male characters in the play. In Leicester he created a foil to both the queens, and he added the figure of Mortimer to enhance Maria's developemnt.

While the historical Elizabeth created an atmosphere in which her courtiers "pretended they were smitten by her charms long after those charms had withered,"12 in Schiller's play the English queen has none of Maria's grace when it comes to the relationship with her servants and retainers. Elisabeth leaves Dudley no doubt that he belongs in the latter group. In their conversations they give an illustration of how unequal their stations are (M.II,9). Leicester knows he will not advance to the throne as king or even become Elisabeth's consort. Consequently, he speaks in flattering terms and Elisabeth gives the impression that she wants to believe he is all hers. Yet Maria is between them. When Dudley persuades the queen she should go to Fotheringhay to see Maria, the monarch makes it very clear the responsibility is Leicester's. Elisabeth sees that the visit could turn out to be a mistake and her answer to Dudley illustrates her refusal to take the responsibility for the arrangement. She states: "Begeh ich eine Torheit, / So ist es Eure, Leicester, nicht die meine /" (M.II,9). She will not even shield her favourite. She can commit an act of foolishness as a person; but as a queen she cannot afford to acknowledge that she had 
any knowledge of the venture.

Just as Leicester gets to feel Elisabeth's lack of consistency and abhorrence of the onus of her station in life, her secretary Davison must carry the burden and punishment the queen metes out when she refuses to take responsibility for handing over Maria's death warrant. Elisabeth is brusque and impatient (M.IV, 11). She delegates her power to a person who she knows full. well can only act on what she tells him to do. The queen will not give him a firm answer as to what he is supposed to do with the document. When Davison begs her to take the paper back, she tells him to do what his office entails (M.IV, 12). As a consequence the secretary does hand over the death warrant to Wilhelm Cecil, Count of Burleigh. Maria is executed and the secretary is sent to the Tower (M.V, 14). The historical Elizabeth had the same trait of vacillation. She "hated to make decisions which could not later be revoked."13 Her hesitation during the revolt in The Netherlands when she could not make up her mind whether to give the uprising her support or not, 14 corresponds to her wavering treatment of the death warrant, both in reality and in the play.

The queens' attitude towards the institution and office of ruler and realm is also expressed in terms which differ significantly. Maria states that she had dreamed of uniting England and Scotland in order that the two people might live in peace and forget about fighting one another just as the 
two factions in England itself were united after the War of Roses $(M . I, 7)$. Elisabeth in contrast has only complaints about the burden England is to her. Elisabeth calls her position "slavery" and she is tired of the fight to remain on the throne (M.IV, 1). Moreover she reproaches her father for his way of life which has made it difficult for her both as a monarch and a woman. Last not least Maria has caused her so much vexation that Elisabeth declares the Scottish queen must die. Only then can the English queen get peace, both as a person and a monarch $(M . I V, 11)$. It is a historical. fact that Henry the Eighth made it hard for her to be acknowledged as a ruler of England, due to his break with the Catholic Church. Because of that the pope and his church considered Mary, Queen of Scots, the rightful heir of England.15 Once Maria is dead Elisabeth shows no compunction and she states her feelings freely:

Jetzt endlich hab ich Raum auf dieser Erde. - Was zittr' ich? Was ergreift mich diese Angst? Das Grab deckt meine Furcht, und wer darf sagen, Ich hab's getan! Es soll an Tränen mir. Nicht fehlen, die Gefallne zu beweinen! (M.V,12).

She admits to wanting to play a hypocritical role at the news of Maria's death and she clearly states she was the one who initiated the serving of the death warrant.

The fact the two monarchs were cousins played a role in the way they viewed one another. They are both proud of their lineage. The Scottish queen speaks of Elisabeth as "Elisabeth 
ist meines stammes, meines / Geschlechtes und Ranges - Ihr allein der Schwester, / Der Königin, der Frau kann ich mich Bffnen" (M.I,2). Maria was referring to their common ancestor, Henry VII, and Schiller uses the relationship to further deepen the rift between the two.

Elisabeth views Maria as someone who is definitely not weak. Schiller expresses this in his use of the word "Geschlecht" which means both sex and lineage. The English queen says: "Das Weib ist nicht schwach. Es gibt starke Seelen / In dem Geschlecht - ich will in meinem Beisein / Nichts von der Schwalche des Geschlechtes h8ren" (M.II,3). The English monarch had overcome the hardship she had had to endure on account of her father, Henry the Eighth, because of his unorthodox way of life. Her knowledge that she herself had been able to withstand the adverse treatment paired with her awareness of her family's history in general made Elisabeth realise that Maria was no less capable and strong.

In Schiller's play the queens' looks play an important role as indeed they had done in the historical reality (see above p. 12). Elisabeth is very conscious of her plain looks. She states: "Es kostet niehts, die allgemeine Schonheit / $\mathrm{Zu}$ sein, als die gemeine sein fUr alle! (M.III,4). She is jealous of Maria and begrudges her success with men and the impression she makes on them. At the same time the English queen is curious about what the Scottish queen looks like because she had heard so many rumours about Maria's beauty 
(M.II,9). She asks:

Und ist's dern wirklich wahr, dass sie so sch bn ist? So oft musst' ich die Larve rlhmen hbren, Wohl mocht' ich wissen, was zu glauben ist. $\cdot \cdot$

Nur meinen eignen Augen wllrd' ich traun. (M.II,9).

In this exchange Schiller made use of an historical incident when the English queen asked the Scottish ambassador to compare herself to Mary, Queen of scots. The hardpressed man answered as best he could and ended his response by telling Elizabeth that she did dance "higher and more composedly" than Mary. 16

The personal envy gets into the monarchal jealousies the English queen feels. Her selfrighteousness and insensitivety pours forth when she talks to Leicester about her own possible marriage. She contrasts herself to Maria and what she perceived as the Scottish queen's free life. She is envious and feels sorry for herself:

Sie hat der Menschen Urteil nichts geachtet. Leicht wurd' es ihr, zu leben, nimmer lud sie Das Joch sich auf, dem ich mich unterwarf, Hatt' ich doch auch Anspruche machen kunnen, Des Lebens mich, der Erde Lust zu freuen, Doch zog ich strenge königspflichten vor. Und doch gewann sie aller Manner Gunst, Weil sie sich nur befliss, ein Weib zu sein.(M.II,9).

The English queen is concerned with decorum. This is expressed on two occasions. The circumstances surrounding the marriage of Ann Boleyn and Henry the Eighth made Elisabeth appear illegitimate in the eyes of the Catholic Church and that was a source of embarrassment to the English queen. For 
that reason she was advised by Burleigh to stay out of a situation of confrontation with Maria. However, the conditions in which Maria is kept are a source of concern to Elisabeth. These worries are less prompted by compassion than by apprehension about the talk that might circulate, and she says:

Nicht wohlanstăndig. wär' mir's, die Verwandte Im Mangel und in Schmach zu sehn. Man sagt, Dass sie nicht kbniglich umgeben sei Vorwerfend war' mir ihres Mangels Anblick. (M.II, 9).

This concern is used by Dudley to urge Elisabeth to agree to a meeting with Maria. That way the English queen could, indeed, see for herself. Maria sends a letter to Elisabeth requesting a meeting with the English monarch. When Elisabeth has read the letter she states:

. . Wie weit ist diese k8nigin gebracht, Die mit so stolzen Hoffnungen begann,

Die auf den lyltsten Thron der Christenheit Berufen worden, die in ihrem sinn

Drei Kronen schon aufs Haupt zu setzen meinte! Welch andre sprache flurt sie jetzt als damals, Da sie das Wappen Englands angenommen

Und von den Schmeichlern ihres Hofs sich Konigin

Der zwei britann'schen Inseln nennen liess. (M.II,4).

but she continues a while later referring to both to " England's enemies" and to Maria:

Doch Ewig wankt die Kron' auf meinem Haupt, Solang sie lebt, die ihrem Schwärmeeifer Den Vorwand leiht und ihre Hoffnung ndhrt. (M.II,5).

In spite of Burleigh's warning against the meeting Elisabeth listens to Leicester's pleas. Dudley is eager to see Maria. To egg the British queen he calls Maria "queen of a small throne" which she could not hold on to (M.II,3), a 
papist, and Darnely's murderess (M.II,9). Leicester stands to lose a lot at the meeting. Maria has sent him a letter and her picture through Mortimer, and he is concerned about Walsingham, chief of Elizabeth's intelligence service, who might get to know the correspondence. Both walsingham and Burleigh hate Dudley (M.II,8). If they find out that he has had any communication with Maria he might lose both his position at Elisabeth's side and his life. If on the other hand Mortimer should succeed in freeing Maria he might be able to go abroad with her. He does know that this is a gamble. Maria will most likely die; Elisabeth will never marry, and his only prospect is to remain Elisabeth's knight in armor; but as mentioned, he will never become her consort.

Just as Leicester laments the fact that Elisabeth is at this point in full charge of his life, Maria has a realistic view of her own plight. She gives vent to her feelings when she says: "Ich bin die Schwache, sie die Măcht'ge - Wohl! / Sie brauche die Gewalt, sie tote mich, / sie bringe ihrer Sicherheit das Opfer." (M.I,7).

Elisabeth can also be devious and plotting. Before the meeting with Maria she attempts to hire Mortimer as an assassin to get rid of Maria and again thus to save herself from making the decision about the death sentence. She tells Mortimer that he is fortunate for he has no idea of how cruel the people can be in its judgement of actions which she deems the populace unable to fathom. She also tells him how clever 
she must be to cover her tracks so that she can not be traced as the instigator of Maria's murder (M.II,5).

Where Elisabeth pities herself for all the work she has to do Maria has learned from her experiences. She has not grown bitter and wrathful. She shows political insight when she talks about the Scots and their historical equality to the British. Old wisdom, she points out to Burleigh, says: "Es kann der Brite gegen den Schotten nicht Gerecht sein" (M.I, 7), and the consequence is that in court, "kein Brite gegen den Schotten, / Kein Schotte gegen jenen zeugen darf." (M.I, 7). The Scottish queen continues:

Kein Feind bedralnget Engelland, dem nicht Der Schotte sich zum Helfer zugesellte; Kein Bllrgerkrieg entzllndet Schottlands stydte, Zu dem der Brite nicht den Zunder trug. Und nicht erldschen wird der Hass bis endlich Ein Parlament sie brlderlich vereint, Ein Zepter waltet durch die ganze Insel.(M.I, 7). (see also p. 21)

The meeting between the two queens is arranged. As a prelude Maria's physical imprisonment is relaxed a little. She is allowed to walk outside the castle after a long confinement. The scottish queen in convinced she can thank Dudley for this pleasure. She enjoys the outing in full. measure and says to Hanna:

Lass mich der neuen Freiheit geniessen, Lass mich ein Kind sein, sei es mit! Und auf dem grünen Teppich der Wiesen Prlfen den leichten gefllgelten Schritt.

Lass mich in vollen in durstigen zllgen Trinken die freie die himmlische Luft. (M.III,1). 
As they hear hunters outside the walls the Scottish queen daydreams about hunting in the Highlands. Her enjoyment is shattered when Paulet, her jailor, comes to inform her that the English queen is near.

The unexpected intrusion of the long awaited visitor causes Maria to lose her composure. She panicks. She wants inside, she feels fear because she is not prepared for the sudden opportunity to confront her adversary, and she is close to hysteria when she says: "Ich kann sie nicht sehen! Rettet, rettet mich von dem verhassten Anblick" (M.III,3). Only when Talbot, Count of Shrewsbury, assures her that Dudley has arranged the meeting, does she regain her countenance. She is ready to meet Elisabeth with the same logical reasoning she displayed in her conversations with Paulet; but the meeting is a disaster.

There is no doubt in Maria's mind that she and Elisabeth are equals. The Scottish queen reminds her counterpart:

- Ihr habt an mir gehandelt, wie nicht recht ist, Denn ich bin eine Konigin wie Ihr, Und Ihr habt als Gefangene mich gehalten; Ich kam zu Euch als eine Bittende, Und Ihr, des Gastrechts heilige Gesetze, Der vilker heilig Recht in mir verhbhnend, Schlosst mich in Kerkermauern ein, die Freunde, Die Diener werden grausam mir entrissen. Unwllrdigem Mangel ward ich preisgegeben, Man stellt mich vor ein schimpfliches Gericht -. (M.III, 4 ).

Though a sovereign over a free country she has been treated as a vassal and she finds that unforgivable. She acknowledges she is powerless and promises to abdicate any claim to the 
English throne. She expresses her resigned mood when she says, "Nicht Grbsse lockt mir mehr, - Ihr habt's erreicht," (M.III,4), and she continues, "Ihr habt das Musserste an mir / Getan, habt mich zersturt in meiner Blute!" (M.III,4). Maria is bodily imprisoned, but her spiritt is not a captive. The scene with Elisabeth, as did the earlier scene with Paulet, clearly shows her mind is still agile. Just as the Scottish queen challenged her jailor and questioned him concerning the English system of justice she now states that Elisabeth has imprisoned her and broken her trust or at least the trust which should exist among monarchs. The Scottish queen does realize that she herself took the initiative to go to England. She came to Elisabeth with a request and counted on the right to hospitality, which was not honored (M.III,4). Though others have kept the flame of envy alive between them, Maria feels they should be able to meet on equal terms now they are finally face to face. Maria implores Elisabeth to state the charges against her; but the English queen comments:

Nicht die Geschicke, Euer schwarzes Herz Klagt an, die wilde Ehrsucht Eures Hauses. Nichts feindliches war zwischen uns geschehen, Da kllndigte mir Euer Ohm, der stolze, Herrschwll'ge Priester, der die freche Hand Nach allen Kronen streckt, die Fehde an, BetOrte Euch, mein Wappen anzunehmen, Euch meine kónigstitei zuzueignen, Auf Tod und Leben in den Kampf mit mir $\mathrm{Zu}$ gehn - wen rief er gegen mich nicht auf? Der Priester Zungen und der volker Schwert, - $\cdot$ Meinem Haupte war / Der Streich gedrohet, und das Eure fullt (M.III,4). 
Elisabeth further declares that nobody feels like becoming Maria's fourth husband, whereupon the argument recedes into the most personal of personal realms. Maria loses all control and she gives vent to her frustration when she says, "Das ist zuviel!" (M.III,4). The Scottish queen declares Elisabeth a bastard. She signs her own death warrant when she says:

Der Thron von England ist durch einen Bastard Entweiht, der Briten edelherzig Volk Durch eine list'ge Gauklerin betrogen. Regierte Recht, so laget Ihr vor mir Im Staube jetzt, denn ich bin Euer König. (M.III,4).

The Scottish queen's dignity has been attacked and her physical freedom taken away. She has, however, learned to live with that. When Maria lets herself be baited into the argument with Elisabeth and when she loses her temper and thus her life she fulfills Kierkegaard's notion that "The hero stands and falls entirely on his own acts," as well as "the hero's destruction is really not suffering but action."17 The two queens are unable to cooperate. They can meet neither as relatives, nor as queens, nor as wornen.

Elisabeth becomes enraged because of Maria's attitude. She had expected to find a humbled person, not one who is still able to arouse people. Now she is even more reinforced in her resolve to rid herself of the threat to her personal happiness as well as the threat to the English people and the Church of England:

Nein diese Furcht soll endigen!

Ihr Haupt soll fallen. . .

Sie ist die Furie meines Lebens.

- . Maria stuart

Heisst jedes UnglUck, das mich niederschlagt! (M.IV,10). 
Though the English queen has total power over Maria and the freedom to do as she pleases, she cannot stop and reflect upon her station in life and what would be the humane thing to do. She can not listen to Maria's plea for life and then graciously consider what was said after the meeting was over. The fact that Leicester is present may further have excited Elisabeth to give her opponent the coup de grace. The meeting and the remarks prior to it showed the two queens' development as people rather than as two monarchs, trying to come to grips with two very complicated questions, one the line of succession and the other, the question of religious faith. Was the Anglican Church or the Catholic Church going to play the dominant role in England? The English queen attacks the scottish queen ruthlessly although she knows she has Maria in her power. She becomes very personal in her attacks. This causes the Scottish queen to move from monarchal to religious and hence to personal matters, which gives her the last word in the discussion, and seals the death sentence.

Subsequent to the fateful meeting, Maria has learned to control her instincts and become what schiller elsewhere calls "an elevated beautiful soul."18 she is portrayed in such a fashion that she possesses those qualities which Schiller values highly when he says: "The highest degree of dignity is majesty."19 She has internalized the control of her instinct which is Schiller's prerequisite for "eine 
schlne seele. "20

After the climactic meeting with Elisabeth, Maria soon regains her poise and she keeps it all through the denouement. Only once does she shed tears and that is when she sees Paulet's pain over his nephew's, Mortimer, work. Maria prepares herself for death through receiving communion one last time. She feels God is with her once she realizes that unexpectedly and unbeknown to her captors there is a priest, Melvil, at her side. As mentioned earlier her confession contains statements about former hate and passion both of which have dissolved and she also expresses guilt feelings about the murder of Darnley. She can now as a consequence say her last prayers in a strong voice. Her experiences have purified her. Maria has achieved the peace Hanna had wished her earlier in the play (M.I,4).

The reception of Maria Stuart by Schiller's contemporaries was mixed. The confession scene was one facet which caught the critical eye unfavourably. The other was the fact he let two women speak rudely to one another on open stage. A third point was the adjustment of the Mary stuart figure to fit his intentions of making her the heroine rather than Elizabeth.

Schiller did not quite succeed in shifting the focus. Three acts (I, III, and V) are devoted to Maria; two (II and IV) belong to Elisabeth, but the latter also appears in acts II and $V$, hence one must say the poet gave Elisabeth a prominent role as she indeed had historically. 21 However, 
because of the changes the poet made in the Maria figure she has become a strong-minded heroine. She grows from being a pleasure-seeking young woman to a reflective, mature person. She is consistent in her consideration of her servants and aides. She has been fond of flattery and flirtation in her youth, but at the time of the play she does not want any more frivolity. She wants sincerity. She seeks God and finds peace when her priest is at her side, just as she found comfort in the company of her nurse, Hanna. Her strength is revealed when she accepts the death sentence with dignity. She does not cry over her own fate, only Paulet's pain over Mortimer's actions makes her cry. She is indeed ready to "stand and fall on her own actions" as a true Kierkegaardian heroine (see above, p. 30).

The British monarch is the weaker character of the two queens because she does not manage to combine pleasure and duty; or as Schiller says: "Der Mensch soll Lust und Pflicht in Verbindung bringen er soll seiner Vernunft mit Freuden gehrochen." 22 The cruelest expression of her inability to listen to her own reason comes in her treatemnt of her secretary Davison, when she lets him take the responsibility for the death warrant. Once the sentence has been carried out she shows herself even smaller when she sends Davison to the Tower. Schiller's Elisabeth lives up to her historical reputation for hating to "to make decisions which could not later be revoked." (see above p. 21 ). 
Elisabeth is also afraid her hands will appear soiled once Talbot brings to her attention that the Babington letters are false $(M, V, 13)$. Talbot is painfully aware of her weakness of character when it comes to taking a firm stand. He hands the English queen his resignation when she takes her revenge on Davison. His words, as he does so, illustrate how deeply he has recognized her weakness: "Ich habe deinen edlern Teil nicht retten k8̈nnen." (M.V,15). Through her inability to take a stand and show compassion for her underlings she is left with nobody. All she has is the crown.

Maria, on the other hand, had always time for her underlings. Historically up to the very moment Mary stands on the scaffold she takes her time to see to it that her servants get what she had decided to give them of her belongings and she intercedes for them in the last minutes before her beheading, when she feels their rights are threatened.

Schiller also portrayed "Elisabeth as self righteous about ruling even though this is not an historical fact; but it heightens the drama as the flaw in the English queen's character stands in contrast to the Scottish queen's warmth and greatness (M.II, 4+9). Maria grows in dignity as indeed she did in history. When the Scottish monarch had lost her worldly possessions, she realized and accepted their transient value. This was expressed on her return to Chartley when Mary proudly told Paulet that she is, ". . left with the two things which could never be taken from her - her royal 
blood and her Catholic religion."23 schiller used a similar line when he had Maria say:

Nun hab ich nichts mehr

Auf dieser Welt - Mein Heiland! Mein Erloser!

Wie du am Kreuz die Arme ausgespannt,

So breite sie jetzt aus mich zu empfangen. (M.V,9).

When the curtain fell after the first performance on June 14 , 1800 it must have been clear to the audience that Maria had, indeed, experienced catharsis and that she had made peace with herself and the world. 
NOTES

1 walther Killy ed., Goethe-Schiller Briefwechsel (Frankfurt am Main: Fischer Bllcherei KG, 1961), p. 408-9.

2 Friedrich Schiller, Lyrik und Asthetik (Hamburg: Hoffmann und Campe Verlag, 1957), p. 380.

3 Friedrich Burschell, Friedrich Schiller (Hamburg: Rowohlt Taschenbuch Verlag GmbH., 1958), p. 118.

4 ibid. p. 118.

5 ibid. p. 118.

6 David Harris Willson, A History of England Hinsdale, Ill.: Holt, Rhinehart, and Winston, Inc., 1972), p. 280 .

7 Antonia Fraser, Mary Queen of Scots (New York: Dell Publishing Co., Inc., 1971), p. 524.

8 ibid. p. 596.

9 In this thesis quotes from Maria stuart will be marked M. for the drama, Roman numeral for the act, and Arabic numeral for the scene.

10 Schiller, Lyrik und Asthetik, p. 373

11 Fraser p. 244.

12 Willson p. 271.

13 ibid. p. 269.

14 ibid. p. 294.

15 ibid. p. 280. 
16 ibid. p. 273 .

17 Sфren Kierkegaard, Either-or, trans. David P. Swenson and Lillian M. Swenson, ed. Howard A. Johnson, Vol. I (Princeton: Princeton University Press, 1971), p. 141 .

18 Schiller, Lyrik und Asthetik, p. 380.

19 ibid. p. 389 .

20 ibid. p. 373.

21 That Schiller's shift of focus remains problematic for the interpretation of the play is born' out by the title of the follwoing paper to be presented as this thesis is completed: "Schiller's Maria Stuart: Hermeutical Problems of One Tragedy with Two Queens", Andreas Mielke, SUNY at Stony Brook, Stony Brook, NY at the Friedrich von Schiller Conference, Nov. 8-10, 1984, Hofstra University, Hempstead, N.Y .

\footnotetext{
22 Schiller, Lyrik und Asthetik, p. 370.

23 Fraser p. 574.
} 
CHAPTER III

PENTHESILEA

As mentioned in the introduction, Goethe turned Heinrich von Kleist down in a letter of February 1st, 1808. It was the play Penthesilea that Goethe did not find agreeabie. He said:

Mit der Penthesilea kann ich nich noch nicht befreunden. Sie ist aus einem so wunderbaren Geschlecht und bewegt sich in einer so fremden Region, dass ich mir zeit nehmen muss, mich in beide zu finden.

(see note 7, "Introduction").

According to a letter of June 7 th, 1808 from Heinrich von Kleist to Johann Friedrich Cotta, the publishers were also scared. They would only take the drama on comission. The consequence was a delay in the staging of the play. It was not performed until 1876 when it was staged in Berlin. In 1927 it was made into an opera. The reason for the initial cool reception of the play was Winckelmann's one-sided Apollonian concept of antiquity: "Die Penthesilea war ein Schlag ins Gesicht der Antikenverehrung Winckelmanns, Goethes, Schillers, Humboldts."1

But Kleist was not the only writer to produce a play which received a cool reception. Schiller also shared this treatment with him in as much as his Maria stuart had been met with unfavourable criticism when first performed. 
Schiller, however, was the more fortunate of the two. First, his play was staged during his lifetime, shortly after it was written, and second, the criticism came from peers and friends to an established writer. When Kleist sent the drama to Goethe he was seeking the approval of his elder. He wanted the boost it would be for his writing to have the established leader of German letters put his stamp of approval on one of his works. When Goethe turned Kleist down it spelled personal, artistic, and financial ruin for the writer. But it must be said Goethe was not entirely negative in his letter of February 1, 1808. He did leave room for kleist to come back to him, be it with a revised version of the play or some other work. Kleist had at the time but so little success that he could ill afford such an effort and thus he could only take the answer as a rejection.

He had to overcome yet another stumbling block because, "In many German theatres plays were still acted only in French. This is one of the external reasons why Kleist found so few theatres to perform his plays." 2

Heinrich von Kleist gave no clues as to when he first developed the idea of writing about the queen of the Amazons. There is evidence Kleist carried the manuscript with him since his second Swiss journey which took place in 1802.3 He was very involved with writing the play. One story told by pfuel recounts how the poet came dashing into his room one evening, hysterical and crying, "She 
is dead, oh, she is dead." When asked who had died he answered, "Penthesilea, my Penthesilea."4

From letters and notes one forms the impression he had worked on the play in K8nigsberg 1806 and 07, Chalons 1807, and finished it in Dresden during the summer of 1807 . In June of 1808 Kleist offered it to Cotta for publication.5 His contemporaries had varying opinions about the play. Most famous is Goethe's refusal to stage the play; but there were others who remarked upon the drama. Uhland was very favourable in his comment about Penthesilea. In a letter to Karl Mayer of February 28th, 1808 he said, "Der neue Phybus hat - . treffliche Fragmente aus einem Trauerspiel Kleists: Penthesilea." 6 Varnhagen was also positive in his remarks in a letter to Rahel of February 23rd, 1809. He calls it a "Meisterwerk."7 Fouque was not quite so generous. In a letter to Varnhagen, written at Numhausen on the 19th of February 1808, he said," . . so wahnwitzig mir die Penthesilea freilich erscheint so spllre ich doch eine gewisse Vorliebe fllr sie." 8 Then there was woman, Dora Stock, who wrote from Dresden on the 11th of April, 1808 to a literary figure of the time, F.B. Weber: ". . seine Penthesilea ist ein Ungeheuer, welches ich nicht ohne Schauder habe anhlren k8nnen."9 J. Schreyvogel was no less negative when he wrote about Kleist in Das Sonntagblatt in Vienna in February 14th, 1808: "Seine Penthesilea, der Prolog und Epilog des ersten Heftes sind wahrer Unsinn."10 All in all it was a tower of 
mixed reception with the top leaning towards the negative side. Kleist wrote to Marie von Kleist, his cousin, from Dresden in a letter dated "Spätherbst 1807":

Ich habe die Penthesilea geendigt, von der ich Ihnen damals, als ich den Gedanken zuerst fasste, wenn Sie sich dessen noch erinnern, einen so begeisterten Brief schrieb. Sie hat ihn wirklich aufgegessen, den Achill, vor Liebe. Erschrecken Sie nicht, es lässt sich lesen. - . Pfuels kriegerisches Gemllt ist es eigentlich, auf das es durch und durch berechnet ist. Als ich aus meiner stube mit der Pfeife in der Hand in seine trat, und ihm sagte: Jetzt ist sie tot, traten ihm zwei grosse Trudnen in die Augen. 11

It should also be pointed out that séveral decades before Sigmund Freud, Kleist showed in this play how women and men exhibit male and female features: Penthesilea is a warrior and Achilles shows Penthesilea tenderness and is willing to disarm himself in an attempt to gain her. Another factor is mentioned by Claude David:

Lessing ordnete der Tragldie das Mitleid zu. Als Penthesilea nach ihrer Untat wieder die Scene betritt, wenden sich all mit Schrecken von ihr ab. Sie erregt nicht Mitleid sondern Entsetzen. Sie hat den Zorn der Gltter auf sich geladen. Sie ist entsetzlich und verflucht ${ }_{i 2}$ Kleist hat den Raum des Tragischen wiederentdeckt. 12

In Penthesilea, Kleist succeeded in creating a character embodying a wide range of features. She was an Amazon, that is a warrior maiden, a woman who was at home in the men's world and in women's tasks.

Kleist was influenced by the works of contrasting $18 \mathrm{th}$ century thinkers such as J.J. Rousseau and I.Kant. In a letter of the 22nd of March 1801 to Wilhelmine von zenge, 
his fiancée, he stated he felt the need to combine the disparate. "Wahrheit und Bildung" were of the utmost importance to him. Curt Hohoff remarks in the same vein about the"Kleist Phenomenon":

Grace and despair are interlaced with one another, the earthly and the divine are insidiously separated and locked up. . . In this brittle world there are constantly points where paradise becomes visible: In love, whose place is the leaves, in the cave, the bed and finally - more mysteriously and pregnant than them all - death.13

Sixteen years earlier Nelly Heusser had observed along similar lines what she deemed typical for Kleist: "Die Panerotik, das heisst der werbende Kampf ums du, der Versuch, die Isolation $\mathrm{zu}$ durchbrechen und subjektive und objektive Welt zu vereinigen." 14

The subject matter of Kleist's play has been handed down in various versions. They all agree on the basic myth that Achilles fought in the Trojan War, where he defeated the Ethiopean Mennon as well as the Amazons led by Penthesilea. It appears Kleist had read a version of the myth used as a musical comedy in 1594 called Hercules unter den Amazonen. In this play Achilles falls in love with Penthesilea when he takes off her helmet and sees her beauty. ${ }^{15}$ The myths have Achilles as the main character. Heinrich von Kleist changed the thrust of the story and focused on Penthesilea as the protagonist. She not only finds herself at odds with her social group but she realizes it is impossible to rejoin it after her transgression. She experiences as a consequence 
catharsis and kills herself. Penthesilea is portrayed as a tragic heroine who like Maria stuart fits the Kierkegaardian definition of standing and falling on her own acts. 16 The calamity in kleist's play results from the fact that the writer has juxtaposed two great warriors: Achilles, bloom of Greek manhood, and Penthesilea, queen of the Amazons, blossom of a group of independent women, who had set up rules to avoid being hurt both physically and emotionally. Kleist also juxtaposed the individual and society as a whole. Penthesilea never questioned the demands put upon her until she became aware of the world outside her own society, that is, when she falls in love with Achilles and is faced with the possibility of separation because he can't or won't follow her people's customs. She will not follow him because she can't sever herself from her role as queen or give up her individuality. When the high priestess denounces her, she is lost.

The play starts with the Greeks and the Amazons battling one another; but nobody can fathom why. The ferocity of the battle is expressed in the language of Odysseus. He calls the Greeks and the Amazons "zwei erboste wblfe" (P.1).17 Penthesilea is called "Sturmwind". Odysseus also describes with surprise how she had blushed when she saw Achilles: "Und Glut ihr plotzlich, bis zum Hals hinab / das Anlitz furbt, als schillge rings um sie / die welt in helle Flammenlohe auf." (P.1). Instead of listening to the talk of 
alliance Penthesilea is absorbed in Achilles or as Odysseus says: "Sie wendet / mit einem Ausdruck der Verwunderung gleich einem sechzehnjuhrigen Madchen.. . sich," and shouts, "Solch einem Manne, o Prothoe, ist / Otrere, meine Mutter, nie begegnet!" (P.1). Her remarks are met with $a$ response befitting a sixteen year old. Her friend ist quiet and Achilles and Odysseus smile. At this, Penthesilea reverts to her role of leader of an army. She is now "verwirrt und stolz und wild." (P.1). Right from the start the queen of the Amazons is portrayed as a person with deep feelings and a full range behavior. Achilles is, on the other hand, portrayed in a role which makes him the person next to the center rather than the focal point. We learn little about his emotional reactions in this scene.

Immediately after the first encounter Penthesilea resumes the fight as if she wants to cover her embarrassment, attacking with a fury which unites the Greeks and the Trojans in self-defense. The queen of the Amazons is described as having an emotionless face during the first encounter. Later in action she is described as "wild", that is as a "zentaurin." Kleist describes her battle mood in another way when he talks about her as a thunderstorm, and calls her "Gewitter und Donnerkrachen" (P.1); but as is the case with thunderstorms there was a lot of noise but not too many deadly strikes of lightning. Penthesilea fought to take prisoners, and not to kill (P.1). Diomedes calls her "W8lfin" when he describes 
her saving Achilles' life by killing the Trojan who was to do him in and tells that she turned pale at the threat to Achilles' life. Penthesilea is a puzzle to her male opponents from the outset. To clarify if not solve the riddle, Odysseus decides that Achilles must be removed from the battlefield. The queen is, however, too swift and determined. She is described as "Wetterstrahl", "Wassersturz", and "wilde Uberschwemmung" in her pursuit of Achilles (P.1).

When Penthesilea shows signs of fatigue, the other Amazons try tenderly to stop her pursuit, but to no avail. At this point they are described as "Rasende" (P.2). After a neckbreaking chase up a mountainside Odysseus decides that Achilles must be rescued from the Amazon Queen. Before the plan can be executed Achilles emerges with Penthesilea in tow. The queen behaves like a young girl in love. She can not rationalize the rules of her society and be satisfied with the collective choosing of mates. The encounter with the Greek turns her from the role of active pursuer into that of one who allows herself to be pursued. There is an interesting analogue to Kleist's sister Ulrike who would on occasion dress in men's clothing and travel through occupied territories only to have to return to the passive role of a woman of the Romantic Era.18 The encounter marks the start of Penthesilea's awareness of herself as an individual. The Amazons rescue their queen who is wounded and the Greeks protect Achilles from the Amazons. The Pelide's actions are met with 
approval by the Greeks they call him "G8ttersohn" whereas Penthesilea is called "die Unverwlstliche" and "die Katze" $(P .3)$

At this point in the play Penthesilea is like the puppet in Kleist's essay "Uber das Marionettentheater." The strings attached to her are the rules of the Amazon society which are promulgated most clearly by the high priestess. The queen can only embrace with "iron" (P.5); but not for her own sake. She poses the question, "Denk ich bloss mich, sind's meine WUnsche bloss, die mich zurllck aufs Feld der schlachten rufen?" (P.5). The battle must be crowned with the "Rosenfest." The field is, however, not rich in roses on this day, "Auf diesen Feldern, heil'ge Priesterin ernten Gefangene leichter auch als Rosen sich", this is what the high priestess is told (P.4). The Greek captives are more than puzzled at the roses and the young Amazons.

Penthesilea has a change of heart. She orders the army ready to fight again in the middle of the preparations for the "Rosenfest." Instead of settling for the booty of captured Greeks, Penthesilea goes off for her own personal gain. She cannot rest until she has Achilles. The enemy in her bosom is love. In the ensuing battle Penthesilea falls again. This time it is Achilles who picks her up and calls her back to life. He literally disarms himself in order to pursuade her she should live. The Pelide has also fallen in love. 
Penthesilea now vacillates between the roles of queen and woman. First, she wants to start another battle, then she tells Prothoe of her excited anxiousness about the meeting, and finally questions the rules of the Amazon society, "Ist's meine Schuld, dass ich im Feld der Schlacht um sein Gefthl mich klympfend muss bewerben?" (P.9). This is the only time she questions the rules and the way the Amazons live. She is becoming aware of the world outside her own realm. She does not want to kill Achilles in battle, but win him personally. The high priestess now steps in to remind the queen of her obligations to her society. In her frustration Penthesilea attempts to scatter the roses gathered for the "Rosenfest", though there had been very few gathered. She curses her feelings and wants to break them and the rules like the roses (P.9). She will not run. She will meet Achilles. It is therefore important now to be successful as a woman rather than as a warrior: "Staub lieber, als ein Weib, das nicht reizt" (P.9). She does not once, however, call on the gods, the high priestess, or Prothoe to take the responsibility of her office away from her.

When the other Amazons demand that she run though wounded and expecting the meeting with Achilles, she breaks down and cries. The high priestess is adamant; but Prothoe attempts to protect the queen from the demands. Penthesilea has grown so despondent in the face of these demands that she wants to commit suicide by drowning herself. She is 
stopped by Prothoe and Meroe.

Achilles still follows them and he leads an ambush party which captures the Amazons. Most of the women warriors manage to escape; but Penthesilea and Prothoe can not flee. Meroe is sent off by Prothoe with the words: ". . und wenn du kannst so mach uns wieder frei" (P.12). After a small scuffle the Greeks agree the Amazon queen is Achilles' prize and they pursue the other Amazons instead. Prothoe succeeds in pursuading Achilles to stand aside when Penthesilea awakens after the blow she has received (P.13). Achilles admits he loves the queen and therefore he agrees to hide til she is sufficiently recovered to see him.

Penthesilea wakes up and is convinced she has been humiliated on two counts. She was hit literally, and she was scorned when taken to the Greeks' camp. She becomes calmer once Prothoe and Achilles manage to make her believe she has captured him. Once more she wants to get the "Rosenfest" started; but her happy shouts about the proper preparations bring nobody forth and her anxiety grows again, "Zum Tode war ich nie so reif als jetzt", she adds. "Das Ungllck sagt man lautert die Gemlter" (P.14). A little later she lets her recent feelings pass in review and regrets her negative thoughts. Now she wishes to spread happiness. The queen's recent agony is expressed: "Der Mensch kann gross, ein Held, im Leiden sein. Doch Gbttlich ist er, wenn er selig ist!" (P.14). She has not forgotten Prothoe's plea 
for Lykaon, one of the captured Greeks. Penthesilea has him called, which is contrary to custom, and preparations begin anew for the "Rosenfest." Because of Achilles agreeing to play in the scheme for Penthesilea's sake the scene is like a dream. As the queen believes she has captured Achilles, she makes garlands which she gives him as well as a ring (P.15). The ring can disappear and she wants to know if he has her features memorized. As he professes to have that done she proceeds to tell him her name and the story of her lineage.

To keep her calm and to pass time Achilles wants to know why the Amazons have attacked the Greeks so viciously. In order to perpetuate her dream, she is making Achilles aware of why she has to do battle. In relating the realities of her society the queen regains her senses. The reader or the theatergoer learns together with Achilles about the ways of the Amazon society. To revenge the murder of their husbands and their own rape the women had taken up weapons against invaders. They killed them all, and decided they could properly use a bow if they would amputate the right breast. The left one closest to the heart would be saved. Achilles can't help himself. He can perhaps go along with the thought of women as warriors; but women totally without men he can't imagine. How is the tribe propagated? He can't leave that subject alone.

To that end he is informed, the Amazons have a "Rosen- 
fest." A number of men of neighboring lands would be overcome and taken prisoner and the mating took place. At the end of the "Rosenfest" the Amazons are not necessarily happy; but the custom must be followed. They must part with their men. Achilles may be able to understand the collective choosing of mates; but why was he selected by Penthesilea? The queen tells him it was her mother's choice, expressed on her deathbed. Once Penthesilea arrived at the Troy battlefield the gried from her mother's death had disappeared. She had watched Achilles' treatment of the bereft priam and had wondered what his feelings were at the time. It was then and there she had decided she either had to win or kill him (P.15). The scene suddenly changes. The Greeks are pressing the Amazons. The Pelide has to tell Penthesilea the truth. She is to follow him since she, not he, had been vanquished. She is his prisoner. The fortunes of war are, however, uncertain. In the moment when Achilles professes to be bound by love to Penthesilea he is told the Amazons now have the advantage over the Greeks and he flings the wreaths away. He is ready to do battle. Twice Penthesilea calls on the gods to help her, but to no avail. Achilles is convinced he can take the queen along and build her a temple in his town. It develops into a kind of tug of war between the two. In their discussion they go back and forth between Phthia and Themiscyra until they are separated by their forces. The moment the Amazons triumphantly liberate her, 
Penthesilea decries her fall. She cannot square this battle with the rules she has been taught. The puppeteer, that is the high priestess, steps in to set the records straight. Three times Penthesilea has broken the rules; she must therefore relinquish the throne. She is free to follow her chosen mate and to go as she pleases. The Amazons are going home not to a "Rosenfest" but to everyday life.

Penthesilea feels denounced and crushed. She has set herself outside the rules of her society. As little as the young man in "Uber das Marionettentheater" could repeat the stance of the statue, after he had grown aware of the likeness he had to it, just as little could Penthesilea step back into the role of queen of the Amazons once she had become aware of her love for Achilles and had felt the joy of making decisions for herself. Prothoe stays at her side and admonishes her, "Ein grosser Schmerz traf dich; begegn' ihm gross" (P.19). It is the puppeteer-like high priestess who constantly reminds Fenthesilea of her duties to the Amazon society and its customs. Her remarks make Penthesilea swing in mental ellipsis resembling the movements of a puppet. One moment she is far away from the center that is her pursuit of Achilles. The next she is close to it preparing for the "Fest."

Her trials are not over. Achilles challenges her to a hand-to-hand fight to determine who is going to follow whom to whose temple. This saddens Penthesilea as she thought he 
realized that her society demanded the mate be won in battle. The one good aspect of such a renewed melee would be the possibility of regaining the Greek prisoners of war thereby ensuring the Amazons their "Rosenfest." That is her chance to rehabilitate herself and to regain her position. Mentally exhausted she sets out to do battle with a force which is physically weakened by previous conflicts. Prothoe tries to stop the venture; but Penthesilea is intoxicated with the thought of reversing the unhappy outcome of the earlier battle. She will not listen to anybody. Instead, she gathers her dogs and invokes Ares, the god of war, in order that her plan may succeed.

Achilles is in the Greek camp preparing himself for the encounter under different premisses. He is convinced of Penthesilea's love for him and he loves her too. He views the rules of her society as a whim (P.21). This is a mistake which proves fatal. Like Penthesilea he is warned by his companions, but to no avail. The Pelide is convinced he can call the queen into a mock battle, let her win, become her prisoner, and turn around and bring her home to his throne. He has not understood that her society is as firmly set in its traditions as is his. Achilles believes it is to be a duel whereas Penthesilea comes prepared for a major battle between the two forces. This misunderstanding proves to be devasting for both parties.

In the camp of the Amazons the high priestess tries to 
bring Penthesilea under control. This time it is not the strings of the Amazon society but real rope she wants to apply. Before the plan can be realized Achilles has been caught and torn apart by Penthesilea and her dogs. The gods had taken the utmost revenge on her for casting off the rules of her group. Meroe's description of the moment when Achilles realised that Penthesilea's plan was not his and her report of his last question to Penthesilea, "Ist das das Rosen fest, das du versprachst?" just before dying expresses the despair of the misunderstanding. Achilles had heard her words but not understood the rules by which she had to play. Penthesilea had overstepped the rules of her society. The maiden warriors were to fight and make prisoners for the propagation of the Amazons' race, not fight for the personal possession of one particular man. This is pointed out early in the play, when Penthesilea admonishes Prothoe to stick to Amazon rules (P.5). The queen is now "vom giftigsten der Pfeile Amors . . getroffen" (P.7). The high priestess had realized early on that Penthesilea was on the edge of an abyss when she said: "O sie geht steil bergab den Pfad zum Orkus!" . . "Dem Feind in ihrem Busen, wird sie sinken." (P.7). Penthesilea has fallen in love. She was caught unavoidably by her role as queen to an extent that the conflict within her mind between that role and her feelings as a woman caused the madness which killed Achilles. Once the frenzy of the battle is over she grows calm as Meroe says: 
"Jetzt steht sie lautlos da, die Grauenvolle." She is spent (P.23).

The high priestess now implores the virgin goddess Diana to be her witness that she was not a party to the outrage and she tries to rid herself of Penthesilea by calling her, "die Scheussliche, du Hades-Burgerin" (P.24).. When the high priestess cannot pull the verbal puppet strings on the queen, she again turns to Prothoe to have her help remove Penthesilea. The priestess stands through-out the play in contrast to Penthesilea. Penthesilea takes full responsibility even while relying on her commanders and allies in battle. In contrast, the high priestess takes no responsibility. She either asks Prothoe to do the helping or she invokes the gods to make it clear she was not responsible for any of the events.

Meanwhile the queen is going through the routine of cleaning up after battle. The mundane actions bring about the recovery from her madness. The problem for the Amazons is now to keep the truth of the battle from her. Prothoe is the one who pursuades the queen to get cleaned up and rest. The physical cleaning process brings about a mental cleansing. Once Penthesilea has her head submerged she shows signs of full recovery. She speaks. What she has to say is not comforting: "Ich bin so selig, Schwester! Uberselig / Zum Tode reif, Diana! fuhl - ich mich!" (P.24). The water has washed her mind clear and made her ready. The Amazons 
have not managed to move Achilles' body out of the way. With her growing clearness comes the realization that she did kill Achilles and his body is the heap on the ground.

Penthesilea sees Achilles' wounds and describes them as decorations for the "Rosenfest" of death: "Ach, wie die Knospen frischen Grabduft streuend / Zum Fest fllr die Gewllrme niedergehen!" (P.24). Once again the high priestess admonishes her: "Entferne dich!" As Penthesilea is on her way to full realization of the events it is upon Prothoe to tell her what happened. The queen tries to push it off as lies; but she must accept responsibility for her action. The kiss of death was a bite which she tried to undo by kissing his mutilated body. She states: "Hab ich's wahrhaftig Wort fur Wort getan; / Ich war nicht so verrllckt, als es wohl schien." (P.24). Finally the high priestess' words seem to take effect and they all think the queen will follow them home. But no, she is ready to take the consequence of her acts and follow Achilles. She says: "Ich sage vom Gesetz der Frauen mich los / Und folge diesem Jllngling hier" (P.24). She mockingly surrenders her arms to the Amazons only to turn a dagger on herself. The acts she committed and the role she had been brought up to play could not be united. She was young and strong of mind; but the conflict was too powerful. Penthesilea had experienced catharsis or as George Steiner expresses it: "Tragic personages are educated by calamity and thus reach their fulfilment in 
death."19 Penthesilea does not reject the Amazon Society. Once she' is fully aware of the magnitude of what has happened she takes full responsibility and removes herself.

Penthesilea and die "Jungfrau von Orleans" have common features. They are convinced their missions are just and divinely inspired. The queen of the Amazons was given her mission by her mother Otrere, the representative of the Gods. Johanna was given her mission by voices speaking for God. As a consequence both women were able to go into battle with a single-minded attitude which made them stay on their chosen course and also caused their deaths. The main difference between them comes forth in their relationship to other people. Where Penthesilea shows concern for her companions such as Prothoe and for their happiness, Johanna is concerned with the French nation and she is close to no individual. Penthesilea falls in love and sets herself outside the rules of her society as a consequence. "Die Jungfrau" answers Montgomery: "Ich weiss nichts von der Liebe Bundnis, das du mir beschwbrst" (J.II, 7).20 Because she is a medium, she is incapable of forming lasting relationships. Just as she can not have a love relationship with Montgomery, Johanna has no deep relationship with her family. She views her father and mother as stumbling blocks whereas Penthesilea expresses love for her mother. They both have, indeed, "true rightness that could never slip into wrong"; 21 but they were conceived as two very different characters. 
Where Johanna drifts, Penthesilea acts as does Maria Stuart. Johanna is incapable of handling bott: her personal life and the affairs of state. She dares not try to be both a woman and a savior in the political arena. Penthesilea and Maria Stuart believe, for a while, they can do both. When they find themselves overruled by events they remove themselves. The historical Maria goes to England where she is subsequently imprisoned and in the end killed. Penthesilea commits suicide. 
NOTES

1 Nelly Heusser, Barock und Romantik (Leipzig/ Frauenfeld: Huber \& Co., 1942), p. 93.

2 Curt Hohoff, Heinrich von Kleist 1777/1977 (Hamburg: Rowohlt, 1958), p. 83.

3 Hohoff p. 73.

4 ibid.

5 ibid.

6 Heinrich von Kleist, Lebensspuren, ed. Helmut Sembdner (Mllnchen: Deutscher Taschenbuch Verlag, 1969), p. 172 .

7 Sembdner p. 209.

8 ibid. p. 172 .

9 Heusser p. 73 .

10 sembdner p. 167.

11 Heinrich von Kleist, Sümtliche Werke und Briefe, ed. Helmut Sembdner (Mulnchen: Carl Hanser Verlag, 1982), IV, p. 796 .

12 Heinrich von Kleist, ed. Walter Mlller-Seidel (Darmstadt: Wissenschaftliche Buchgesellschaft, 1967), p. 228.

13 Hohoff p. 11.

14 Heusser p. 100 . 
15 Elizabeth Frenzel, Stoffe der Weltliteratur (Stuttgart: Alfred Kroner Verlag, 1983), p. 6.

16 sфren Kierkegaard, Either-Or, trans. David P. Dwenson and Lillian M. Swenson, ed. Howard A. Johnson, Vol. I (Princeton: Princeton University Press, 1971), p. 141.

17 In this thesis quotes from Penthesilea will be makred P. for the drama and Arabic numeral for the scene.

18 Hohoff p. 42 .

19 George Steiner, The Death of Tragedy (New York: Oxford University Press, 1980), p. 169.

20 Friedrich Schiller, Die Jungfrau von Orleans (stuttgart: Reclam, 1976), p. 55. This drama is referred to as $J$. when quoted. The act is marked by Roman numeral and the scene by an Arabic numeral.

21 Marina Warner, Joan of Arc (New York: Random House, $1982)$, p. 182 . 
CHAPTER I.V

SAPPHO

According to Franz Grillparzer's diary the conception of his play, Sappho, took place after a chance meeting with his friend Doktor Joel in the Prater in the fall of 1817 . The doctor told him that Weigel, the bandmaster, was looking for a text to an opera. The name Sappho came up and this seems to have spurred Grillparzer on. It seemed to him to be the simple story he was looking for. 1 It appears that both the poet and his audience were happy with his choice. The play was well received by the critics, but one exception should be mentioned. Mllner made negative remarks once his suggestions concerning the first act had been rejected by the poet. Thus he seems to have been a spiteful man rather than a sound critic. Other than that everybody, including Goethe and Byron, praised the play and its poet. The acknowledgement was not limited to words. Grillparzer received a total of 1,000 fr. Wiener Whhrung for the performance of Sappho in $1812 .^{2}$ Grillparzer feared that Sappho would be too Nordic; but when the play was finished he wrote in a letter to Karl August Bbttinger on May 16,1818 that he was satisfied with the performance, as were "Ml̆nner von Geist und Einsicht."3 The play was 
overall a much happier venture than both Penthesilea and Maria stuart. This is apparent in the poet's own views, the critics' opinions, and the public at large.

Yet another factor set Grillparzer apart from Schiller and Kleist. As an Austrian he had inherited some of the Spanish influence that was still strong in his country from the time Habsburg ruled both Spain and Austria. The Austrian critic Schreyvogel had translated Calderon's Leben ein Traum, which had its first performance in $1816 .{ }^{4}$ Grillparzer was greatly influenced by Calderon and by the latter's contemporary Lope de Vega. He was as concerned with fate as they were; but he sees it as a concern which is tied to feelings. 5 Accordingly:

Grillparzer findet also das Geschick des Einzelnen nicht im Individuellen sondern auf eine Calderon ganz Hhnliche Weise, im vorgezeichneten Lebensweg. Der Fluch des Schicksals tussert sich als die zugehbrigkeit zu einer Kategorie, zu einem Menschentyp.

The use of destiny, dream, and dreamlike state in sappho is due to Calderon's influence on Grillparzer. ${ }^{7}$ He differs from the other two writers because he became pessimistic and concerned about society as a whole:

Er (Grillparzer) erweitert den Raum auf den das deutsche klassische Drama sich beschralnkt, indem er unter Calderons Leitung, die Freiheit des Willens in Frage stellt, und indem er vor allem, nach Lopes Vorbild die Forderung der Gemeinschaft als das Gewissen des Einzelnen erkennt. Er stellt den Einzelnen dar als Teil einer sozialen Einheit. ${ }^{8}$ Politically he was also alert to the problems of his day. He was concerned about Austria's future. He realized that 
the medieval form of government that is the government based on God-given-right to rule has come to an end. This has led to cunfusion which makes it hard for this poet to find a forum. "Nur wenn er das drohende Schicksal aller voraussagt, dann its er in seiner Rolle." 9

Grillparzer left remarks about the writing process as for instance:

- Schiller war mein Idol, mein Vorbild, und mein sei auf Wege ihn zu erreichen. Das erhob mich ganz naturlich und gab mir Mut und Krafte; dóch durch Goethe ward ich eine ganz andere welt versetzt. 10

Naumann draws in other important influences:

In Kant sah er den vorbildlichen Philosophen. Mit Hegels Philosophie setzte er sich genau auseinander, aber immer wieder mit dem Ergebnis der Ablehnung. In gleicher weise verhielt er sich zur Literatur und Asthetik der deutschen Romantik und ihrer Nachfolger. Er fand sowohl bei Hegel als auch bei den Romantikern eine Vorherrschaft des Intellekts, die seiner Denkart widerstrebte. Fur ihn stand die "empfindung" im Mittelpunkt. 11

Sappho differs from the other two queens because she is not a queen ruling over people. She is the queen of poets. Sappho, like Maria Stuart, is no longer a young woman nor is she old. She is portrayed as middle aged and mature, confident of her work and at ease with her surroundings. Sappho shows compassion for other people. She rescued and raised Melitta, whom she found for sale as a child. She knows her servantslaves and their circumstances well and often mentions them by name. For instance, she calls her slave Rhamnes, "mein treuer" and says: "Artrander, Du auch hier trotzend deines 
Alters Schwluche?" (S.I, 2).12 This is similar to Maria stuart's question concerning her servants' welfare and especially when she asks about her old chamberlain Didier.

Sappho's faults are known to her servants and slaves. Melitta says about her: "Scheint sie auch stolz, mir war sie immer gutig, / Wenn oft auch streng, es barg die scharfe Hulle / Mir immer eine susse, holde Frucht" (S.V,4). Rhamnes seconds that when he says: "Sie zurnte, als sie ging, und ohne Schranken / Wie ihre Liebe ist ihr Zorn" $(S . V, 4)$. The islanders look up to sappho as the one who decides what is right and who judges fairly. For instance when Phaon wants to buy Melitta free the "Landmann" says: "Ob Recht, ob Unrecht, Sappho wird's entscheiden" (S.V,3).

Unlike Maria Stuart, Sappho does not discuss her mistakes with anybody. She calls on her gods to help her sort out her thoughts and feelings; but she despairs over them at times. Once Melitta and Phaon have gone, she implores the gods to give her a sign; but she comes to the following conclusion: "Da ist nicht Hilfe! Sappho hilf dir selbst!" $(S . I I, 8)$. At that point she suspects she has to find her own way out of her confused state of mind. She surmises that she is responsible for her fate. In this she too is an example of Kierkegaard's assumption that "the hero stands and falls entirely on his own acts," and "the hero's destruction is really not suffering but is action."13

Sappho knows she can call on the loyalty of the islanders. 
When she asks them to bring Phaon back, she says, "Ruchet eure Sappho!" (S.IV, 8). In this she differs - partly due to the dissimilar circumstances - from both Penthesilea and Maria stuart. The former does not call on anybody and the latter's concern is that her servants might get hurt, which prompts her to request that they be allowed to leave after her execution (M.V, 8$)$.

In penthesilea two highly significant words are paired, "Kllsse und Bisse" (P.24). Kleist mentions in a letter of June $3 r d, 1801$ that he has read those words in a poem by Gleim. When he first heard the combination of death using kisses and bites Kleist said he laughed out loud. 14 Nonetheless he uses those same words to describe Penthesilea's action towards Achilles. Grillparzer makes use of several pairs of words in Sappho. They illustrate the often contradictory feelings which the poetess admits to, her "liebe unde leit." In S.I,5 e.g. she uses "Ahnung und Erkennen," in S.I, 2 "Schweigen und Erinn'rung," und in S.V,6 "Lieben und Hassen sind ja Rosen." They point to tensions within the main character.

Roses are used extensively in Penthesilea because of the "Rosenfest" in which the Amazons celebrate their victories. Grillparzer also plays with that flower. He has Melitta wear one (S.II,5). Flowers in general are used to decorate Sappho's house. Another similarity between the two plays is the use of unconsciousness. Penthesilea faints 
after the battle with Achilles (P.3 and 12 as well as after the final battle, P.22). Sappho grows faint and is found in a stupor by her servants at daybreak $(S, V, 1)$. Tears likewise play a role in both Penthesilea and Sappho. After killing Achilles the queen of the Amazons weeps (P.24). The queen of the poets weeps when Phaon defends Melitta's rose (S.III, 6). The tears indicate their awareness of what has happened. No specific flower is mentioned in Maria Stuart. But the crucial meeting between the two queens takes place in the garden at Fotheringhay. Thus nature plays an important role in all three plays.

Sappho, Penthesilea, and Maria are described as caring people. Up to the moment Maria goes on the scaffold she asks for just treatment of her servants. Penthesilea is crushed when she realises the "Rosenfest" is not going to be celebrated because of her actions. Sappho saw Melitta for sale, bought her, and brought her up. She was a mother to her. Yet there is inequality both of rank and sex. In spite of Melitta's feelings and expression of affection for sappho she is not allowed to run and greet her. Rhamnes reminds the girl of her position as a servant in the household, along the traditional lines of "a woman's place is in the home" (S.I,1).

The crisis between the two women comes when they are no longer mother and daughter, owner and slave, but two women competing for the same man. The time span from the joyful celebration of Sappho's homecoming after her crowning 
at the poetry contest at Olympia on mainland Greece to her suicide is 24 hours, as required by classic dramatic tradition. Melitta is impressed with Phaon's appearance from the very beginning. Even as Rhamnes sends her into the house, she notices the person at Sappho's side: "Hoch eine andre glunzende Gestalt, / wie man der Leier und des Bogens Gott / $\mathrm{Zu} \mathrm{Bil-}$ den pflegt." (S.I, 1).

Once the initial greeting has taken place Sappho grows irritated with Melitta because she is not full of immediate praise of Phaon. The poetess words, "Furwahr dich hassen k\&nnt' ich!" $(S, V, 5)$ are similar to Penthesilea's outburst to Prothoe, "Schweig, Verhasste!"(P.5). Both speak harshly in moments of infatuation to the person closest to them, whereas Maria Stuart has no such outburst to Hanna Kennedy, because years of captivity mellowed her once fiery temperament.

Sappho's attitude towards Melitta changes quickly. No sooner has she expressed her ability to hate the girl than she turns around and calls her, "liebes Kind, mein Kind," and furthermore she wants to be called her "Freundin, nicht die Gebieterin," (S.I,5), insisting she be seen as Melitta's sister as well. At first, the girl appears unaware of any change in Sappho's attitude as she sees her as mother, sister, and friend. But gradually, as the poetess continues to philosophize about the merits of the crown she has won, Melitta grows uneasy and through her questions she reveals Sappho's 
volatility and vulnerability at this juncture (S.I,5).

Sappho is well aware of the fact that phaon is much younger than she is. Her jealousy is close to the surface. Once she sees Phaon and Melitta together it bursts forth. She mocks Melitta's picking of roses up high with the remark, "Vielleicht nicht hoch genug!" (S.II,5). When the girl has left, Sappho can not help herself. She has to ask Phaon about the conversation between the two. Sappho cannot refrain from telling him about Melitta, her upbringing, and why she keeps her as a slave rather than setting her free. She stresses Melitta's simplicity and asks that he leave the girl alone in order that she may not be hurt. She wants to spare her the pain of unrequited love (S.II, 6 ).

The poetess now withdraws to meditate. She can't push away her art. Just as she could not enjoy winning the wreath alone she can not submerge herself in her love affair. She is too complex a person. Earlier she had stressed that she was not happy to win the contest for her own sake but for the enjoyment of coming home to share it with her people:

Un euretwillen freut mich dieser Kranz, Der nur den Burger ziert den Dichter arllckt, In eurer Mitte nenn ich ihn erst mein!

Hier dunkt mir dieser Kranz erst kein Verbrechen Hier wird die frevle Zier mir erst zum Schmuck! (S.I, 2).

The poetess also wants to share the joy of Phaon with the islanders. She praises him in front of them and tells them how he pulled her from the spheres: 
Er war bestimmt in seiner Gaben Fulle, Mich von der Di.chtkunst wolkennahen Gipfeln In diesen Lebens heitre Blltentllier Mit sanft bezwingender Gewalt herabzuziehn.

$$
(\mathrm{S} . \mathrm{I}, 2) \text {. }
$$

Moreover she wants to retire with Phaon to a simple life that will put her, the queen of poets, on a par with the common people. Henceforth they will be able to love rather than admire her. But is all this within her power? The duality of her situation is expressed when she laments her lost youth:

Lasst mich zurllckekehren in die zeit, Da ich noch scheu mit runden Kinderwangen, Ein unbestimmt Gefuhl im schweren Busen Die neue Welt mit neuem Sinn betrat;

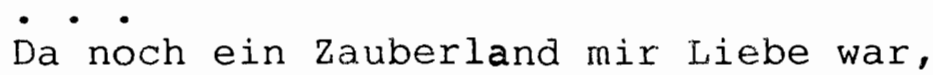
$(S . I, 5)$.

Sappho feels sie stands at a crossroad:

- Da steh ich an dem Rand der weitem Kluft, Die zwischen ihm und mir verschlingend gahnt; Ich seh das goldne Land herlberwinken, Mein Aug erreicht es, aber nicht mein Fuss! $(S . I, 5)$.

She seerns to have a premonition that this love is not for her. Sappho is painfully aware of the fact that she is no longer in her youth and that this could turn out to be the greatest stumbling block. Even though the love may wither like her wreath, the poetess knows for certain her art has the approval of the gods. To improve the chance of success of her love affair Sappho beseeches Aphrodite, the goddess of love, in an ode, to stand by her in this earthly venture with as much help as she had bestowed úpon 
her earlier $(S . I, 6)$.

Phaon for his part is caught in the glamour of it all. At the same time he is awestruck and worried about his parents' reactions, particularly since his father is prejudiced against female poets. While sappho has a feeling of being pulled down to earth, Phaon has a feeling of reaching high out of his regular mileu. They are both expressing a feeling of uncertainty concerning their ability to reach the other's world. Phaon voices his wonder, "Jetzt frag ich noch und steh und sinn und zaudre!" (S.II, 1).

In spite of her awakening concern about Phaon and Melitta, Sappho wants to carry out her usual hour of meditation. She can, however, not find peace because of her jealousy and her thoughts concerning the deep, profound feelings in women versus the ease with which she feels men move from love affair to love affair. Sappho wanders out of the grotto and stands by Phaon when he awakens with the name 'Melitta' on his lips. The poetess has thus gained certainty of her suspicion whereas phaon is still unaware of his feelings. His dreams reflect rapture. The end of his dream reveals his beginning awareness and desire for Melitta, "Das Antlitz . . du bist's und bist es nicht." All this in S. III, 1 .

This scene is the climax of the play. What follows is the denouement. No sooner has Sappho found her fears confirmed than she laments her descent from the heights 
of the muses to the sphere of the mortals, where she is but a woman, whose love is unrequited. Death is her only way out because:

Wen Gltter sich zum Eigentum erlesen, Geselle sich zu Erdenblirgern nicht;

$\cdot \cdot \cdot$

Von beiden welten eine musst du whhlen, Hast du gewhltt, dann ist kein Rllcktritt mehr;

$(S . I I I, 2)$.

Sappho calls Melitta in an attempt to sort out her thoughts and feelings. The girl has put on her finery to celebrate Sappho's homecoming. This upsets the poetess further. She strikes up a conversation about Melitta's childhood and tells how she used to comfort her and help her like a mother. The encounter ends with Sappho ordering Melitta to change her clothes to her usual simple attire so as to make the girl return to her former simplicity. The poetess knows what Melitta can but suspect. The incomprehensible conversation brings the girl to tears which almost soften Sappho; but the rose which Melitta wears breaks the spell. Sappho demands she hand it over and Melitta vehemently refuses to give it to her. At that, Sappho's jealousy comes forth. The poetess threatens the girl's life with a knife.

Phaon rushes to Melitta's aid. His intervention prevents the catastrophe. Phaon now gives Sappho the mental coup de grace, by stating his predilections: "Dass stiller Sinn des Weibes schbnster Schmuck, / Und das der Unschuld 
heitrer Blumenkranz / Mehr wert ist als des Ruhmes Lorbeerkronen" (S.III,6). He expalins to Melitta that it was the magic of Sappho's songs which blinded him to the point of incapacitating him. Melitta had opened his eyes and Sappho herself had just now freed him from the enchantment by wielding her knife. The verdict of being called a 'sorceress,' the deprivation of lover and child leaves Sappho defeated. (S. III,6).

The poetess laments her losses. Her sense of reality vanishes. She had wanted to commit the murder of what amounts to her child. She had wanted to play god and raise Phaon to her own exalted position. Now she endeavors to arrange things even more extensively. She wants to remove Melitta to bring things back to prior conditions. Sappho is accustomed to command because she is a slave owner and a creator of poems. She knows she has the power to raise Melitta to full freedom or push her out into misery. Yet the poetess feels her own loneliness stronger, because of her abandoning her art and the impending loss of Phaon. Only the removal of Melitta can make her newly adopted world whole.

The reaction of Phaon and Melitta strike Sappho as an expression of ingratitude which she also felt earlier in her brothers and sisters (S.I,3). According to Sappho, it is the worst vice a person can have. It is a snake (S.IV,1 and 2). Because Melitta is the cause of Phaon's 
diversion she must leave. Rhamnes is ordered to take her to Chios to an islander who owes Sappho a favor. While the poetess can give the order to remove the girl she can not face Melitta. Sappho has not the fortitude to tell the girl what has happened, let alone why (S.IV,5). Rhamnes tries to fulfill Sappho's wish but is stopped by Phaon. The commotion brings about three changes. First Rhamnes will no longer have Melitta call him father because of her perceived ingratitude. Second, Phaon is informed by Rhamnes that Sappho can count on the support of all the islanders. Third, Phaon declares Melitta his bride and flees with her (S.IV,5).

Sappho's anger turns to frustration because the gods are not reacting to her besseching words. The wind that moves the ship from shore seems to her to be arms helping the refugees. She has to help herself with assistance from her people. The islanders sense that Melitta is in her way, so they promise to bring only Phaon back. She consents by the way she expresses her gratitude, once again attempting to play god by taking fate into her own hands. She is exhausted and sinks into a stupor several hours long $(S . I V, 8)$.

Sappho awakens when the capture of Phaon and Melitta is announced, but she can not face them. Once again she seeks solace from Aphrodite. She remains at the altar while Phaon argues with the islanders about the purchase of Melitta. The return of the slave girl becomes the issue 
for Sappho once she acknowledges Phaon's infatuation in herself is gone $(S, V, 2$ and 3$)$.

Like Maria Stuart and Penthesilea, Sappho has a final talk with the love of her life. Maria wished Leicester luck and happiness at the feet of Elisabeth $(M, V, 9)$. Leicester, once he is alone admits his loss to himself, "Was hab ich verloren! Welche Perle warf ich hin!" (M.V,10). Penthesilea and Achilles have a lovers' tug-of-war about who is to follow whom (P.17), and once Penthesilea has fatally wounded Achilles he asks her, "Ist dies das Rosenfest, das du versprachst:",(P:23)\% Phaon recalls Sappho's poetry and her songs. How he used to feel uplifted. Now he feels that same poetess has turned human. He wants her to return to her godly state, "Zeig dich als Glttin! Segne, Sappho! segne!" (S.V,3). Phaon, like Leicester and Achilles, has lost both his naivete and his exalted love. Phaon has gained Melitta and joined the human race, whereas his counterparts Leicester and Achilles lose either their human dignity (Leicester) or their life (Achilles).

Sappho's inner fight is about to end. Through Phaon's words she has gained certainty about her true place in the world. She does not belong among ordinary human beings. She has her special place above the islanders but below the gods. She was destined to guide and judge and to write her portry, not to join in the ranks of ordinary human beings. The pains she feels at the loss of Phaon 
and Melitta renders her speechless. Phaon sums up her position when he together with Melitta implores: "Den Menschen Liebe und den Gyttern Ehrfurcht, / Gib uns was unser, und nimm hin, was dein! / Bedenke, was du tust und wer du bist!" $(S . V, 3)$.

Sappho retreats hastily. Rhamnes now reminds Phaon of what he gained from his meeting with sappho. The slave asks who Phaon thinks he is to measure himself against the greatest poetess in Greece, who created verses for eternity. Phaon can only be remembered as the person who killed her. Sappho is the creator of Melitta as well. That is the reason why Phaon finds her so likeable, Rhamnes thinks. Because of the events on the island and in case of Sappho's death it is certain that Phaon will be looked upon as an outlaw $(S \cdot V, 4)$.

Sappho meanwhile has worked through her crisis. She knows she has lost in her quest for a life as an ordinary human being. Schiller's Johanna was not allowed to fall in love and to lead the life of an ordinary human being, either. However, Sappho is a well-educated and highly gifted person whereas Johanna, die Jungfrau, is an uneducated supposedly simpleminded girl, who feels she has a calling to save France. Where Sappho is aware of people and their shortcomings Johanna is naive in her relationships with people both her immediate family and potential lover. She is incapable of forming close ties with either. Because 
of her intelligence and gifts Sappho grows aware of her mistake of falling in love with a young man. She feels she should have recognized that he felt drawn to her aura rather than to her person. The poetess has furthermore lost her child.

While Rhamnes is lecturing Phaon she is readying her house and herself for death. The poetess flings her belongings and ornaments into the ocean as if to prepare her place in the hereafter. Sappho dresses herself in her cloak and clasps her lyre. She has accepted. She is poetess first and woman second. The gods have reaccepted her and she is ready to join them $(S, V, 5)$. Thus dressed Sappho can face the two lovers and part with them in quiet dignity. She compares herself with the bow, "Gebeugt erst zeigt der Bogen seine Kraft!" $(S, V, 6)$. She gives the two young people her approval. She offers thanks to the gods for all her gifts and, as her work is accomplished, she asks to be allowed to end her own life, "Gebt mir den Sieg, erlasset mir den Kampf!" $(S, V, 6)$. Sappho has found herself and is heard by the gods. Picking up Phaon's words from S.V, 3, she forgives the lovers and blesses them:

Den Menschen Liebe und den Glttern Ehrfurcht! Geniesset, was euch bluht, und denket mein! So zahle ich die letzte schuld des Leben, Ihr Gbtter, segnet sie und nehmt mich auf! $(S . V, 6)$. Sappho, like Penthesilea, has taken the consequences of her actions and paid with her life. She meets death as 
serenely as Maria Stuart goes to the scaffold; she leaps into the sea. Sappho, like the old man in Grilparzer's prose work Der arme Spielmann, chose to remain true to herself and make peace with herself. The poetess could as little as he fit into the mundane society surrounding her. Sappho could not form a lasting relationship with Phaon. He was as far removed from her as the grocer's daughter was from the old man once he had lost his inheritance. They belonged to the world of the arts, not the world of human love. As to Sappho's experience of growth and catharsis, Grillparzer leaves no doubt. Turning to Phaon just before the end she says: "Ich suchte dich und habe mich gefunden." $(S \cdot V, 6)$. Through passion and suffering she reached insight and heroic strength. 
NOTES

1 Franz Grillparzer, Dichter Uber ihre Dichtungen, ed. Rudolf Hirsch und Werner Vordtriede, (Wien: Wienerstadt Bibliothek, 1853; rpt. Heimeran, 1970), p. 109.

2 Franz Grillparzer, Sappho, ed. Keith Spalding, (New York: St. Martin's Press, 1965), p. 120.

3 Franz Grillparzer, Dichter..., p. 103.

4 walter Naumann, Franz Grillparzer, (Stuttgart:

w. Kohlhammer, 1967), p. 129 .

5 Naumann p. 133.

6 ibid. p. 134.

7 ibid. p. 166.

8 ibid. p. 155.

9 ibid. p. 47.

10 Franz Grillparzer, Dichter..., p. 46.

11 ibid. p. 11.

12 In this thesis quotes from Sappho will be marked s. for the drama, Roman numeral for the act, and Arabic numeral for the scene.

13 Sфren Kierkegaard, Either-Or, trans. David P. Swenson and Lillian M. Swenson, ed. Howard A. Johnson, Vol. I (Princeton: Princeton University Press, 1971), p. 141 . 
14 Heinrich von Kleist, Sămtliche Werke und Briefe, ed. Helmut Sembdner, (Munchen: Carl Hanser Verlag, 1982), IV, p. 657 . 


\section{CHAPTER V}

\section{CONCLUSION}

Romanticisim was a rebellion against rationalism. It was a change from a movement wich stressed reason and analysis to a reliance on feelings to guide human life and interaction. Coexisting with romanticism was classicism which sought to combine feelings and intellect. Its purpose was to synthesize the two with a result perceived to be the classical Greek notion of "Edle Einfalt, stille Grbsse" as Winckelmann had phrased it. In 1868, when looking back upon the era, Franz Grillparzer said, "Und dann der fatale romanische Name! Romantik! Romantik. Nun, so nenne mich auf deutsch! Ich. Wie also denn? Romantik. Die Jugend."1 For the romantics the individual was in the center rather than society as a whole.

Part of the Romantic program was originated by Jean Jacques Rousseau (1712-1778) who stated, "Le sentiment est plus que la raison." 2 Writers of the two movements worked at a time when Europe seemed to be undergoing a rebirth. The French Revolution had shaken values and mores. The upheavals following in its wake made room for experiments within social relationships as feudalism ended, the guild structure weakened, and the Jews were emancipated. In 
addition women had greater freedom and possibilities for escape. This is reflected in the drama of the period. Schiller's Maria Stuart, Heinrich von Kleist' Penthesilea, and Grillparzer's Sappho stand out as examples and they are equal in power to the central characters in Don Carlos, Friedrich von Homburg, and kbnig Ottokars Gluck und Ende by the same writers.

What makes these three women figures remarkable is that they overcome adverse situations rather than succumbing to them. They are unlike Brunhilde/Kriemhilde in the Nibelungenlied and the title figure of Mutter Courage und ihre Kinder by $B$. Brecht. Neither achieved cleansing through catharsis. Instead their hatred and/or destructive aspects were brought to full bloom. Similar unproductive reactions can also be observed in male figures in times of tension. Yet, the three female characters discussed in this thesis appear in a period when Germany and the German speaking area were undergoing very difficult times. Austria was the only country within the area to take up arms against Napoleon. When it was defeated the Holy Roman Empire was declared null and void in 1806 as a result. The three writers all had experienced strong feelings concerning the French Revolution and Napoleon, feelings that changed with the developments of the time.

Schiller at first greeted the French Revolution as a step in the right direction. He was even declared an 
honorary French citizen by the French National Assembly in 1792 "wegen seiner Verdienste um die Sache aer Freiheit."3 He despaired though, when he heard of the events that followed the Revolution and said, "Der grosse Moment hat ein schwaches Geschlecht gefunden." Burschell comments," • - mit diesem echt Schillerschen Satz fasste er seine Abkehr von der zeitgenbssischen Politik zusammen." 4 Schiller had been confined to the Karlsschule during his formative years and could not remain enthusiastic about a group of people who caused oppression of their fellow man. However, this did not dampen his desire for frredom. But he no longer approved of the French Revolution. He turned to reading history and focused on the Elizabethan reign and especially the trial of Mary, Queen of Scots. This led him to write Maria Stuart.

Heinrich von Kleist came to loathe Napoleon. He was shaken by the destruction the Napoleonic Wars were causing. In the 7th chapter of Katechismus der Deutschen 1809 he says about Napoleon that he reagrds him,

FUlr einen verabscheuungswlldigen Menschen fur den Anfang alles BUsen und das Ende alles Guten; fur einen Sunder, den anzuklagen, die Sprache der Menschen nicht hinreicht und den Engeln einst am jungsten Tage, der odem vergehen wird. ${ }^{\text {. }}$

He further calls him, "Vatermurdergeist" in the same piece.

Kleist was arrested by the French occupation forces and taken to France as a prisoner of war. During the transfer the poet had occasion to observe the destruction of war 
first hand. These experiences may have been the cause of his outlook,

So wird Geschichte fldr Kleist - ganz im Gegensatz zu Schiller - nicht zum Sinnbild einer dberzeitlichen Gottesordnung, sondern zu einer ganz realen, irdischen Wirklichkeit. . . Da fllr Kleist das Irdische vom Ewigen schlechthin untrennbar ist, ist diese Wirklichkeit der Ort, wo der Mensch seine ewige Bestimmung erfuhrt. . . Kleists Welt zerbrach, als ihm die Relativitat der menschlichen Erkenntnis bewusst wurde. - Es ist Tatsache, dass Kleist nach der Kant-Krise dem Gefthl mehr Gewicht beimass als dem Verstand. 6

In other words, Kleist's own awakening to the realities of life and war is reflected both in Penthesliea and in "Uber das Marionettentheater" where he describes what happens when a person become aware of self and the world in general.

Franz Grillparzer was also under the spell of the time. He wrote Sappho in 1817 after the Congress of Vienna, where in 1814-15 all the crowned heads of Europe decided they wanted to return to regimes approximating those of pre-Napoleonic times. Politically Grillparzer had no great reason for optimism. He suffered infringements upon his freedom of expression, because he had to submit his plays to the censor before publication. While he did not suffer personal confinement as had both Schiller and Kleist, his artistic freedom was limited. By mid 19 th century Franz Grillparzer had grown so pessimistic he said, "Der Weg der neuern Bildung geht von Humanityt durch Nationalitat zur Bestialitat."7

While none of the three writers said they chose a 
female hero in order to make a statement about a human being and human conditions, they and other writers have done so when the German speaking areas were in crisis or in post-crisis times. For example, Brunhilde and Kriemhilde in the Nibelungenlied are such persons. Though the epic was written in the 12 th century it can be traced to the time of the Migrations. Grimmelshausens account Lebensbeschreibung der Erzbetrügerin und Landstorzerin Courasche is yet another example. It was written after the Thirty Years War. In this century several dramas can be mentioned, e.g. Die Heilige Johanna der Schlachthßfe by B. Brecht which was written during the Great Depression between the two wars. Ernst Toller's play Masse Mensch written in 1921 is another example. After the second World war the picture is less clear; but Heiner Mlller's Weiberkombdie seems to be a case in point. Furthermore, it should be mentioned that Glnter Grass in his book Der Butt also postulates that remarkable times call for remarkable women. Using the story about the flounder he tells how women have managed to do what they wanted--or what the writer sees them as wanting--disputing the menial women tending pots in the kitchen. Indeed Grass sees no steteotype tending to pots. He sees this as a key to a power base. Through cooking women have exerted great power over men and thus over the course of history. Grass uses the adage that the road to a man's heart is through his stomach to say that the way 
to political change is through the kitchen. As women have traditionally been keepers of the kitchen they have the power to strongly influence the course of history, but only in the background.

The question is, of course, whether women are satisfied with their "background power." Many contemporary women feel they have outgrown the stage of influencing the course of events only indirectly. By creating strong-minded woman figures in their plays over 150 years ago, Schiller, Kleist, and Grillparzer provided some role models. In the works discussed above, these authors appear ahead of their personal predelictions.

It should be noted that the three poets in question chose to portray their female heroes in tragedies rather than in comedies. They did not set out to "improve through laughter" as Lessing stated the purpose of comedy. All three authors most likely lacked the necessary optimism or faith in progress that would be required for a Lessingean comedy. J.M.R. Lenz' drama theory may have been closer to their needs than Lessings. Lenz held: "Der Hauptgedanke einer Kombaie wäre eine Sache, einer Tragddie eine Person."8 By focusing on strong-minded woman figures they each created an archetypal heroine who possesses traits common to entire peoples or epochs. 9 The writers have created "a symbol - . which recurs enough in literature to be recognizable as an element of one's literary experience."10 
Nor did Ibsen create a comedy with his famous play A Doll's House, written one hundred years ago. Nora's slamming of the door has echoed through the literary world, but for the most part women have remained to this day in supporting roles. Comedy presupposes that a change of conditions is possible and that laughing at present limitations can bring this change about. Heiner Muller with his Weiberkombdie of 1975 attempts to do just that and even more recently Lee $R$. Edwards expresses the revaluation that is taking place:

Psyche's heroism, like all heroism, involves both doing and knowing. The pattern of the tale parallels the growth of consciousness. . . The possibility of woman hero is contigent only on recognizing the aspirations of consciousness as human attributes; . - Heroism thus read and understood is human necessity, capable of being represented equally by either sex. 1 
NOTES

1 Franz Grillparzer, Ausgew Berichte (MUlnchen: Carl Hanser, 1964), III, p. 699.

2 w. Grabert \& A. Mulot, Geschichte der deutschen Literatur (Munchen: Bayerischer Schulbuch-Verlag), p. 165.

3 Friedrich Burschell, Friedrich Schiller (Hamburg: Rowohlt Taschen Verlag GmbH., 1958), p. 115.

4 ibid. p. 116.

5 Heinrich von Kleist, sumtliche werke und Briefe, ed. Helmut Sembdner (MUnchen: Carl Hanser Verlag, 1982), III, p. 354 .

6 Hermann Reske, Traum und Wirklichkeit im Werk Heinrich von Kleists (Stuttgart: W. Kohlhammer Gmbh., 1969), pp. 5464 .

7 Walter Hollerer, Zwischen Klassik und Moderne (Stuttgart: Ernst Klett Verlag, 1958), p. 282.

8 J.M.R. Lenz, Werke und Schriften I, ed. Britta Titel und Helmut Haug (Stuttgart: Henry Goverts Verlag GmbH., $1966)$, p. 361 .

9 C.G. Jung, Psychological Types, trans. H.G. Baynes, ed. R.F.C. Hull (Princeton: Princeton University Press, 1976), p. 443.

10 Northrop Frye, Anatomy of Criticism (Princeton: 
Princeton University Press, 1957), p. 365.

11 Lee R. Edwards, Psyche as Hero (Midaleton: Wesleyan University Press, 1964), p. 11. 


\section{A SELECTED BIBLIOGRAPHY}

Boesch, Bruno, et. al. Deutsche Literaturgeschichte in Grundzllgen. Bern: A. Francke AG Verlag, 1961. Burschell, Friedrich. Friedrich Schiller. Hamburg:

Rowohlt Taschenbuch Verlag Gmbh., 1958.

Edwards, Lee R. Psyche as Hero. Middleton: Wesleyan

University Press, 1984.

Fraser, Antonia. Mary Queen of Scots. New York: Dell Publishing Co. Inc., 1971.

Frenzel, Elizabeth. Stoffe der Weltliteratur. Stuttgart:

Alfred Körner Verlag, 1983.

Frye, Northrop. Anatomy of Criticism. Princeton: Princeton University Press, 1957.

Grabert, W. und A. Mulot. Geschichte der Deutschen Literatur.

Mlnchen: Bayerischer Schulbuch-Verlag, 1965.

Grillparzer, Franz. Ausgewăhlte Briefe, Gesprăche, Berichte.

Munchen: Carl Hanser, 1964.

Grillparzer, Franz. Dichter lber ihre Dichtungen. Ed.

Rudolf Hirsch und Werner Vordtriede. Wien: Wiener-

Stadt Bibliothek, 1853. Rpt. Heimeran, 1970.

Grillparzer, Franz. Sappho. Ed. Keith Spalding. New York:

St. Martin's Press, 1965.

Hermann, Helmut G. "Zur Diskussion." Die Frau als Heldin 
und Autorin. Ed. Wolfgang Paulsen. Bern und Mllnchen: Francke Verlag, 1977 .

Heusser, Nelly. Barock und Romantik. Leipzig/Frauenfeld:

Huber \& Co., 1942 .

Hohoff, Curt. Heinrich von Kleist 1777/1977. Hamburg:

Rowolt, 1958.

Hollerer, Walter. Zwischen Klassik und Moderne. Stuttgart:

Ernst Klett Verlag, 1958.

Jung, C.G. Psychological Types. Trans. H.G. Baynes.

Ed. R.F.C. Hull. Princeton: Princeton University Press, 1976.

Kierkegaard, Sфren. Either-Or. Trans. David P. Swenson and

Lillian M. Swenson. Ed. Edward A. Johnson. Vol. I.

Princeton: Princeton University Press, 1971.

Killy, walther, ed. Goethe-Schiller Briefwechsel.

Frankfurt am Main: Fischer Bllcherei KG., 1961.

Kleist, Heinrich von. Lebensspuren. Ed. Helmut Sembaner.

Munchen: Deutscher Taschenbuch Verlag, 1969.

Kleist, Heinrich von. Sämtliche Werke und Briefe. Ea.

Helmut Sembdner. Munchen: Carl Hanser Verlag, 1982.

Lenz, J.M.R. Werke und Schriften I. Ed. Britta Titel und

Helmut Haug. Stuttgart: Henry Goverts Verlag GmbH. , 1966. Muller-Seidel, Walter, ed. Heinrich von Kleist. Darmstadt:

Wissenschaftliche Buchgesellschaft, 1967.

Naumann, Walter. Franz Grillparzer. Stuttgart: W. Kohlhammer, 
Reske, Hermann. Traum und Wirklichkeit im Werk Heinrich von Kleists. Stuttgart: W. Kohlhammer GmbH., 1969. Schiller, Friedrich. Die Jungfrau von orleans. Stuttgart: Reclam, 1976.

Schiller, Friedrich. Lyrik und Msthetik. Hamburg: Hoffmann und Campe Verlag, 1957.

Schiller, Friedrich. Maria Stuart. Stuttgart: Reclam, 1976. Steiner, George. The Death of Tragedy. New York: Oxford University Press, 1980.

Warner, Marina. Joan of Arc. New York: Random House, 1982. Willson, David Harris. A History of England. Hinsdale, Ill.: Holt, Rhinehart and winston, Inc., 1972. 